\title{
Techno-economic assessment of an integrated high pressure chemical-looping process with packed-bed reactors in large scale hydrogen and methanol production
}

\section{Citation for published version (APA):}

Spallina, V., Motamedi, G., Gallucci, F., \& van Sint Annaland, M. (2019). Techno-economic assessment of an integrated high pressure chemical-looping process with packed-bed reactors in large scale hydrogen and methanol production. International Journal of Greenhouse Gas Control, 88, 71-84.

https://doi.org/10.1016/j.ijggc.2019.05.026

\section{Document license:}

TAVERNE

DOI:

10.1016/j.ijggc.2019.05.026

Document status and date:

Published: 01/09/2019

\section{Document Version:}

Publisher's PDF, also known as Version of Record (includes final page, issue and volume numbers)

\section{Please check the document version of this publication:}

- A submitted manuscript is the version of the article upon submission and before peer-review. There can be important differences between the submitted version and the official published version of record. People interested in the research are advised to contact the author for the final version of the publication, or visit the $\mathrm{DOI}$ to the publisher's website.

- The final author version and the galley proof are versions of the publication after peer review.

- The final published version features the final layout of the paper including the volume, issue and page numbers.

Link to publication

\footnotetext{
General rights

- You may freely distribute the URL identifying the publication in the public portal. follow below link for the End User Agreement:

www.tue.nl/taverne

\section{Take down policy}

If you believe that this document breaches copyright please contact us at:

openaccess@tue.nl

providing details and we will investigate your claim.
}

Copyright and moral rights for the publications made accessible in the public portal are retained by the authors and/or other copyright owners and it is a condition of accessing publications that users recognise and abide by the legal requirements associated with these rights.

- Users may download and print one copy of any publication from the public portal for the purpose of private study or research.

- You may not further distribute the material or use it for any profit-making activity or commercial gain

If the publication is distributed under the terms of Article 25fa of the Dutch Copyright Act, indicated by the "Taverne" license above, please 


\title{
Techno-economic assessment of an integrated high pressure chemical- looping process with packed-bed reactors in large scale hydrogen and methanol production
}

\author{
Vincenzo Spallina $^{\mathrm{a}, *}$, Goharsharieh Motamedi ${ }^{\mathrm{b}}$, Fausto Gallucci ${ }^{\mathrm{b}}$, Martin van Sint Annaland ${ }^{\mathrm{b}}$ \\ ${ }^{a}$ Department of Chemical Engineering and Analytical Science, University of Manchester, Manchester, United Kingdom \\ ${ }^{\mathrm{b}}$ Department of Chemical Engineering and Chemistry, Eindhoven University of Technology, Eindhoven, the Netherlands
}

\section{A R T I C L E I N F O}

\section{Keywords:}

chemical looping

methanol

hydrogen

packed bed

energy analysis

CCUS

\begin{abstract}
A B S T R A C T
A full-scale techno-economic analysis of a novel chemical looping based process using dynamically operated packed bed reactors has been carried out for the large-scale production of hydrogen (up to $30,000 \mathrm{Nm} / \mathrm{h}$ ) and methanol (up to 10,000 tons per day) with inherently integrated $\mathrm{CO}_{2}$ capture. The complete process is carried out in three main reactors, in which the reactions occurring are the dry and steam reforming of natural gas with $\mathrm{H}_{2} \mathrm{O}$ and $\mathrm{CO}_{2}$, the oxidation of the oxygen carrier (OC) with air and the reduction with a low-grade fuel such as plant off-gases. The thermal balance of the process is achieved by combining the endothermic reforming reaction with the exothermic chemical looping combustion. The chemical looping based process is fully integrated with the separation and synthesis units as well as the power and heat utilities of the two large scale production plants. The two plants are compared with state-of-the-art technologies, including the benchmarks for hydrogen and methanol production from natural gas through steam reforming and auto-thermal reforming. Compared to a conventional $\mathrm{H}_{2}$ production plant (without $\mathrm{CO}_{2}$ capture), the reforming efficiency is $3 \%$ higher, while the required primary energy consumption to separate $\mathrm{CO}_{2}$ is $0.47 \mathrm{MJ} \mathrm{JHV}_{\mathrm{LH}} / \mathrm{kg}_{\mathrm{CO} 2}$ which is significantly lower than that of an amine-based plant ( $>1.35 \mathrm{MJ}_{\mathrm{LHV}} / \mathrm{kg}_{\mathrm{CO} 2}$ ) and the cost of hydrogen production with the proposed process is $2.19 \$ / \mathrm{kg}$ with a $\mathrm{CO}_{2}$ avoidance cost of $58.7 \$ /$ ton $_{\mathrm{CO} 2}$ (compared to $>70.6 \$ /$ ton $_{\mathrm{CO} 2}$ for solvent based plant). In case of methanol production, the carbon conversion is comparable with the best available processes even though $\mathrm{CO}_{2}$ purification and separation ( $98 \%$ capture with $>96 \%$ purity) units are included due to the improved energy recovery. By using chemical looping the cost of methanol production decreases overall by $17 \%$ compared to the benchmark plant due to the lower investment cost and higher electricity generation resulting overall in a negative $\mathrm{CO}_{2}$ avoidance cost $\left(-303 \$ /\right.$ ton $\left._{\mathrm{CO} 2}\right)$.
\end{abstract}

\section{Introduction}

Hydrogen $\left(\mathrm{H}_{2}\right)$ and gas-to-liquid (GTL) products such as methanol $(\mathrm{MeOH})$, ammonia $\left(\mathrm{NH}_{3}\right)$ and Fischer-Tropsch fuels are among the most important chemical products in the market, and their global demand is satisfied for more than $60 \%$ by natural gas (NG) and oil/naphtha reforming (Muradov and Veziroğlu, 2005). However, the conventional reforming technology is responsible for a large part of the $\mathrm{CO}_{2}$ emissions from chemical industries (IEA, 2015) and is accompanied by high costs. Natural gas reforming can be performed in a so-called fired tubular reforming (FTR) reactor where the natural gas reacts with $\mathrm{H}_{2} \mathrm{O}$ to form syngas inside tubes filled with catalyst and where the tubes are immersed in a furnace using part of the fuel to supply the heat for the endothermic reaction; a second option is the auto-thermal reforming (ATR) where an oxidant (air or pure oxygen) is fed with natural gas (NG) and $\mathrm{H}_{2} \mathrm{O}$ to form syngas in an adiabatic reactor (Appl, 2006; Cheng and Kung, 1994; Fiedler et al., 2000; Haussinger et al., 2012). In order to reduce the greenhouse gas emissions resulting from this process, different options have been proposed in recent years to capture $\mathrm{CO}_{2}$ from reforming and water gas shift (WGS) processes (Collodi et al., 2017), mostly based on solvent absorption and membranes, which are both hampered by high capital and/or operating costs (Abanades et al., 2015).

Chemical looping technology is an efficient alternative to separate $\mathrm{CO}_{2}$ during the fuel conversion step. Chemical looping combustion (CLC) is based on a metal oxide, also called oxygen carrier (OC) which

\footnotetext{
*Corresponding author at: Department of Chemical Engineering and Analytical Science, The Mill (Room C72), Sackville Street, M13 9PL Manchester, United Kingdom.

E-mail address: vincenzo.spallina@manchester.ac.uk (V. Spallina).
} 


\begin{tabular}{|c|c|}
\hline \multicolumn{2}{|c|}{ Nomenclature } \\
\hline AR & Air reactor \\
\hline AGR & Acid Gas Removal \\
\hline ASU & Air Separation Unit \\
\hline ATR & Auto-thermal reforming \\
\hline CCA & carbon capture avoidance, $\$ /$ ton $_{\mathrm{CO} 2}$ \\
\hline CCF & Capital Charge Factor \\
\hline CCR & Carbon capture rate \\
\hline CCUS & Carbon capture, utilisation and storage \\
\hline CL_PB & Chemical Looping with Packed Bed \\
\hline CLC & Chemical looping combustion \\
\hline CLR & Chemical looping reforming \\
\hline $\mathrm{COH}$ & Cost of hydrogen, $\$ / \mathrm{kg}_{\mathrm{H} 2}$ (unless specified) \\
\hline $\mathrm{COM}$ & Cost of methanol, $\$ /$ ton $_{\mathrm{MeOH}}$ \\
\hline $\mathrm{C}_{\mathrm{O \& M}}$ & Operating and maintenance costs, $\mathrm{M} \$$ \\
\hline CPU & $\mathrm{CO}_{2}$ processing unit \\
\hline FTR & Fired tubular reforming \\
\hline GTL & Gas to Liquid \\
\hline HP-IP-LP & High-Intermediate-Low Pressure \\
\hline HRF & Hydrogen recovery factor, - \\
\hline
\end{tabular}

HT-IT-LT High-Intermediate-Low Temperature

HTS/LTS High temperature/Low temperature shift

IGCC Integarted Gasification Combined Cycle

LHV Lower heating Value

M Stoichiometic Number, $M=\frac{\left[\mathrm{H}_{2}\right]-\left[\mathrm{CO}_{2}\right]}{[\mathrm{CO}]+\left[\mathrm{CO}_{2}\right]}$

$\mathrm{MeOH}$ Methanol

MDEA Methyl diethanolamine

MEA Monoethanolamine

MTPD metic tons per day $\left(1 \times 10^{6}\right.$ tons/day $)$

MW Molecular Weight, $\mathrm{kg} / \mathrm{kmol}$

NG Natural gas

OC Oxygen carrier

PSA Pressure swing adsorption

SPECCA Specific Primary Energy Consumption for $\mathrm{CO}_{2}$ avoided, $\mathrm{MJ}_{\mathrm{LHV}} / \mathrm{kg}_{\mathrm{CO} 2}$

TPC Total plant cost. M\$

TOC Total overnight cost, M\$

TASC Total as spent cost, M\$

WGS Water gas shift is alternately reduced in presence of a fuel stream and oxidized while reacting with air (Adanez et al., 2012). Most of the research in chemical looping has been focused on chemical looping conversion of solid fuels (Adánez et al., 2018) using fluidized bed reactor configuration (Mattisson et al., 2018; Song and Shen, 2018). Among different metal oxides such as $\mathrm{Cu}-, \mathrm{Fe}-$, $\mathrm{Mn}$ - based oxides, $\mathrm{NiO}$ is the most studied oxygen carrier for CLC, predominantly supported on $\mathrm{Al}_{2} \mathrm{O}_{3}, \mathrm{TiO}_{2}$ or $\mathrm{ZrO}_{2}$ (Nandy et al., 2016). Similar concepts can be employed in order to convert fuels into syngas through partial oxidation called chemical looping reforming (CLR) in which the OC also acts as catalyst for the reforming and the shift reactions (Luo et al., 2018). The latter process has been proposed in de Diego et al. (2009) and Ortiz et al. (2010) using Ni-based oxygen carriers, because $\mathrm{Ni}$ can also act as catalyst for the methane reforming reactions. Due to differences in catalytic activity and oxygen transfer capacity, different oxygen carrier materials have been considered for the CLR process (Tang et al., 2015). Tso et al. (2018) have calculated that a GTL process for methanol production integrated with chemical looping can reduce the break-even oil prices for natural gas-to-liquids processes by as much as $40 \%$, while satisfying production demands and obeying environmental constraints.

Another possible integration of reforming and chemical looping has been proposed by Ryden and Lyngfelt (2006) and in Stenberg et al. (2018), where the chemical looping reactors act as combustion chambers to provide the heat of reaction to the reforming tubes which are immersed into the fuel reactor where PSA-offgas is converted into $\mathrm{CO}_{2}$ / $\mathrm{H}_{2} \mathrm{O}$. Both concept have been compared from a techno-economic point of view in Spallina et al. (2017b) showing some improvements in terms of efficiency (8-10\% higher) and costs of $\mathrm{CO}_{2}$ avoidance (CCA) ranging from $20-85 € /$ ton $_{\mathrm{CO} 2}$. Similar results has been obtained by Nazir et al. (2018) who assessed the cost of pre-combustion configuration using CLR as a syngas generation technology and by Symonds et al. (2019) for the production of heat for the steam-assisted gravity drainage (SAGD) process in oil sand field and syngas for GTL process.

A different reactor concept has been proposed and recently experimentally demonstrated in a in $500 \mathrm{~W}_{\mathrm{LHV}}$ interconnected circulating fluidized bed (i-FBR) chemical looping membrane reformer (Medrano et al., 2014, 2018): compared to standard CLR process, in this configuration, in-situ pure $\mathrm{H}_{2}$ separation through metallic Pd-based membranes occurs and the fuel species are converted to $\mathrm{CO}_{2}$ and $\mathrm{H}_{2} \mathrm{O}$ so that no other conversion and separation processes are required in the plant resulting in a higher reforming efficiency compared to an existing $\mathrm{H}_{2}$ production plant $(91 \%$ vs $74 \%)$ and a negative CCA $\left(-25 € /\right.$ ton $\left._{\mathrm{CO} 2}\right)$ as reported in Spallina et al. (2016). Similar to that, a membrane assisted chemical looping switching reforming technology have been proposed by (Wassie et al., 2018b) in which the membrane reactor are dynamically operated to circumvent the high pressure stability associated in iFBR. In this case the overall performance is slightly better than benchmark technologies based on amine technologies (CCA lower than 12\%) (Wassie et al., 2018a).

Another concept for $\mathrm{H}_{2}$ production using chemical looping has been demonstrated at the Ohio State University using Fe-based OC combined with an intermediate oxidation stage which is carried out with $\mathrm{H}_{2} \mathrm{O}$ to form pure $\mathrm{H}_{2}$. They found a net efficiency higher than $6 \%-10 \%$ compared to conventional FTR and ATR baseline configuration (Kathe et al., 2016; Nadgouda et al., 2019).

Khan and Shamim (2016) have calculated a cost of $\mathrm{H}_{2}$ production which is s significantly low when compared to the case of steam methane reforming with $\mathrm{CO}_{2}$ capture (about 30\% lower and comparable with $\mathrm{H}_{2}$ production from steam methane reforming technology (1.404 $\$ / \mathrm{kg}$ vs $1.68 \$ / \mathrm{kg}$ ).

Other alternative processes have considered the integration of high temperature solar energy to sustain the reforming reaction (Fosheim et al., 2018; Krenzke et al., 2017) and the integration of sorption-enhanced reforming and chemical looping to simultaneously carry out $\mathrm{H}_{2}$ production and $\mathrm{CO}_{2}$ separation in a single process resulting respectively in a cost of $\mathrm{H}_{2}$ production 8\% lower than a conventional FTR configuration (Fernandez et al., 2017; Martini et al., 2016; Riva et al., 2018).

A different chemical looping concept for both combustion and reforming has been proposed by Spallina et al. (2017a) using packed bed reactor technology (CL_PB). Starting from a previous research project on chemical looping combustion integrated with IGCC for power production (Hamers et al., 2015; Spallina et al., 2013, 2015b) the proof of concept and model validation has been carried out in a $500 \mathrm{~g}$ lab-scale reactor using $\mathrm{Ni} / \mathrm{CaAl}_{2} \mathrm{O}_{4}$ as oxygen carrier previously tested and characterised (Medrano et al., 2015).

In this work, the packed-bed reactor chemical looping technology has been integrated and assessed for $\mathrm{H}_{2}$ and $\mathrm{MeOH}$ production. Despite only two works have been published so far on chemical looping for methanol production, the synergies of the two processes are very promising and therefore this process has been studied and presented with details in this work. The chemical looping process is carried out with packed process at high pressure and fully integrated with the other parts of the plant. The reactor performances are calculated using the existing and validated 1D reactor model. For the selected 
configurations, an economic assessment is carried out and a sensitivity analysis on natural gas cost, reactor cost, and oxygen carrier durability is presented to provide a complete overview of their potential profitability in comparison with current technologies with and without $\mathrm{CO}_{2}$ capture.

In the first part of the paper, the assumptions and methodologies are discussed including the description of the benchmark technologies considered for the comparison; after that the full techno-economic analyses respectively for the hydrogen and methanol production are carried out including the sensitivity analysis and finally the major conclusions are reported.

\section{Assumptions and Methodologies}

\subsection{Benchmark hydrogen production}

The state-of-the-art for $\mathrm{H}_{2}$ production is based on fired tubular reforming plant (FTR) and has been reported in (IEAGHG, 2017) and described extensively in previous works (DOE/NETL, 2010; Martínez et al., 2013; Molburg and Doctor, 2003). In this plant, natural gas (NG) is initially treated to convert sulphur compounds to $\mathrm{H}_{2} \mathrm{~S}$ and saturate any olefins in a catalytic hydrogenation and later adsorb $\mathrm{H}_{2} \mathrm{~S}$ over a bed of $\mathrm{ZnO}$. The NG is then mixed with $\mathrm{H}_{2} \mathrm{O}$ and pre-reformed to convert the higher hydrocarbons before the primary reforming. The pre-reformed natural gas is pre-heated and introduced into an externally heated fired tubular reformer where the gas mixture is converted into synthesis gas (syngas) at $890^{\circ} \mathrm{C}$ in tubes filled with catalyst (generally Ni-based). The reformed syngas is cooled down and fed into the high temperature shift (HTS) reactor to convert the $\mathrm{CO}$ to $\mathrm{H}_{2}$ thus producing a syngas with a residual $\mathrm{CO}$ of around $2.5-3 \%$. Three different benchmark plants have been considered:

1) Base case $\left(\mathrm{H}_{2}\right.$-BC). After cooling the shifted syngas to ambient temperature, a PSA (Pressure Swing Adsorption) unit is used to separate pure $\mathrm{H}_{2}(>99.9 \%)$ and the PSA-offgas is combusted in the reformer burner to supply the heat for the endothermic reactions. The heat for the steam reforming reaction is supplied by burning the PSA-offgas and part of the NG with air in the furnace. Waste heat recovery downstream of the furnace is carried out in convective banks in which the reforming reactants are pre-heated.

2) Mild $\mathrm{CO}_{2}$ capture ( $\mathrm{H}_{2}$-MCC). A second low temperature water gas shift (LTS) reactor is considered to achieve a final CO content below $0.2 \%$ with an overall $\mathrm{CO}$ conversion in WGS section higher than $98 \%$. The $\mathrm{H}_{2}-\mathrm{CO}_{2}$ rich mixture is cooled down and the $\mathrm{CO}_{2}$ is separated from the $\mathrm{H}_{2}$ by means of methyl-di-ethanol amine (MDEA) absorption. The captured $\mathrm{CO}_{2}$ is then released and the solvent regenerated in a desorber column. A PSA is used to separate $\mathrm{H}_{2}$ at high purity, as in the $\mathrm{H}_{2}-\mathrm{BC}$ configuration. NG and air are feed to the furnace to supply the heat for the reforming reaction and the flue gases are vented to the atmosphere.

3) High $\mathrm{CO}_{2}$ capture $\left(\mathrm{H}_{2}\right.$-HCC). This configuration presents the same conversion and separation units as the base case $\left(\mathrm{H}_{2}-\mathrm{BC}\right)$ but with $\mathrm{CO}_{2}$ capture from the flue gas using mono-ethanol-amine (MEA) solvent post-combustion capture technology. In this configuration, the $\mathrm{CO}_{2}$ separation rate is $90 \%$ (Collodi et al., 2017) and the flue gas is first cooled down to ambient temperature, then compressed to 1.06 bar and sent to the absorber. The $\mathrm{CO}_{2}$ is later separated by the solvent by using LP steam to supply the heat at the reboiler.

The $\mathrm{H}_{2}$ - $\mathrm{BC}$ plant leads to large $\mathrm{CO}_{2}$ emissions (above $840 \mathrm{~g}_{\mathrm{CO} 2} /$ $\mathrm{Nm}_{\mathrm{H} 2}{ }^{3}$ ) to the atmosphere, associated with the combustion of the PSAoffgas and part of the fuel. The $\mathrm{H}_{2}-\mathrm{MCC}$ leads to a $\mathrm{CO}_{2}$ emission reduction of slightly below $65 \%$, while the $\mathrm{H}_{2}$ - $\mathrm{HCC}$ emissions are reduced by $90 \%$ compared to $\mathrm{H}_{2}-\mathrm{BC}$.

\subsection{Benchmark methanol production}

Large scale methanol $(\mathrm{MeOH})$ production from natural gas is typically carried out in an oxygen-blown auto-thermal reforming (AasbergPetersen et al., 2003). In this study, a large scale methanol plant with a capacity of 10,000 MTPD (metric tons per day) (Kim Aasberg-Petersen et al., 2013) has been taken as benchmark technology representative of a methanol-to-olefins production unit. A natural gas to methanol plant combines three different conversion units: oxygen production, syngas generation and methanol synthesis/purification. The $\mathrm{O}_{2}$ required for the ATR reactions is produced in a cryogenic Air Separation Unit (ASU). The ASU modelling is beyond the scope of this work and therefore data from literature are taken from different references (Beysel, 2009; Crotti, 2010; Jones et al., 2011). The ASU is a conventional, cryogenic, pumped liquid oxygen unit that provides oxygen for the reforming process. The ASU is designed to produce $95 \% \mathrm{~mol}$ purity for use in the reformer. The air compressor is powered by an electric motor. The reference for ASU is based on a two thermally integrated separation columns layout. The $\mathrm{O}_{2}$ (with purity of $95 \%$ ) is pumped to the ATR pressure and heated up (where the liquid $\mathrm{O}_{2}$ is evaporated) supplying part of the refrigeration duty to the cooling of the inlet air to the separation column(s). Syngas generation has been studied in two different layouts:

1) Single stage auto-thermal reforming (1s-ATR). In this configuration, NG is combined with oxygen and steam, pre-heated to $680^{\circ} \mathrm{C}$ and fed to an auto-thermal reactor as suggested in (DOE/ NETL, 2014a). The steam-to-carbon ratio (S/C) is equal to 0.3 while oxygen-to-carbon ratio $(\mathrm{O} / \mathrm{C})$ equal to 1.07 . The reforming is accomplished through contacting the reaction mixture with a nickel catalyst supported on alumina. A purified oxygen feed was chosen to minimize the amount of inert gases introduced into the methanol synthesis loop. The ATR operates at (30 bar and $\left.1100^{\circ} \mathrm{C}\right)$. It must be noted that in this case $\mathrm{CH}_{4}$ is converted in a single unit since prereforming would not be feasible unless higher $\mathrm{S} / \mathrm{C}$ ratios would be used. Pure $\mathrm{O}_{2}$ is fed to achieve an overall $\mathrm{CH}_{4}$ conversion $>95 \%$ and a gas mixture of $\mathrm{H}_{2}, \mathrm{CO}$ and $\mathrm{CO}_{2}$ (represented by the stoichiometric number $\mathrm{M}$ (Fiedler et al., 2000) as in equation 1) which maximizes the $\mathrm{MeOH}$ yield;

$M=\frac{\left[\mathrm{H}_{2}\right]-\left[\mathrm{CO}_{2}\right]}{[\mathrm{CO}]+\left[\mathrm{CO}_{2}\right]} \div 1.8-2$

1) Two-step reforming (2s-ATR). The two-step reforming process features a combination of fired tubular reforming (also called primary reformer, operated at mild temperature, $\approx 750{ }^{\circ} \mathrm{C}$ ) followed by an oxygen-fired adiabatic reforming to complete the $\mathrm{CH}_{4}$ conversion as proposed by Haldor-Topsøe (Kim Aasberg-Petersen et al., 2013). In this case, IP steam from the heat recovery and power generation units is mixed with NG (steam-to-carbon ratio of 1.8) and preheated to $500{ }^{\circ} \mathrm{C}$ before being sent to an adiabatic pre-reformer; the pre-reformed syngas is pre-heated to $620^{\circ} \mathrm{C}$ and sent to a primary reforming unit operated at equilibrium conditions at $32 \mathrm{bar}$ and $750{ }^{\circ} \mathrm{C}$. Almost $65 \%$ of $\mathrm{CH}_{4}$ is converted in the primary reformer, while complete conversion occurs in a secondary autothermal reforming unit, to which $\mathrm{O}_{2}$ is fed.

The reformed syngas is cooled to recover heat at a useful temperature to produce HP/IP steam respectively at 100 bar and 40 bar. As the syngas is cooled, process condensate, feed water, and raw water are being heated. The syngas is finally sent to the multi-stage syngas compressor. Part of the electricity required for the syngas compression to methanol synthesis unit is compensated by power generation with a steam turbine.

The methanol synthesis has been designed according to the baseline analysis proposed in the DOE-NETL report (DOE/NETL, 2014a). The process consists of catalytic packed bed reactor operated with vapour 
phase methanol. The reactor is steam cooled to facilitate near isothermal operation at 55 bar and $250^{\circ} \mathrm{C}$. Because the methanol synthesis reaction is equilibrium limited (DOE/NETL, 2014a; Fiedler et al., 2000), the methanol reactor effluent is cooled to condense out the product crude methanol that is removed with a phase separator. In the 1 s-ATR configuration, $95 \%$ of the gases are recirculated and fed back to the methanol reactor along with fresh syngas while the $5 \%$ left is send to a small furnace to generate some heat for the pre-heating of the reactants. In the $2 \mathrm{~s}$-ATR, approximately $16 \%$ of the unconverted syngas is sent to the furnace of the primary reforming and therefore not recirculated to the $\mathrm{MeOH}$ synthesis reactor. The liquid fractions (mainly $\mathrm{MeOH}$ and $\mathrm{H}_{2} \mathrm{O}$ ) enter the first distillation column at 2 bar. $\mathrm{MeOH}$ with $85 \%$ purity enters the second distillation column for additional separation, to reach $>99 \%$ purity.

\subsection{Assumptions and key performance indicators}

The assumptions for the design of the plant and the thermodynamic assessment have been chosen from available literature and validated accordingly (DOE/NETL, 2010, 2014a; EBTF, 2011; IEAGHG, 2017).

1) Reforming units: the reforming reactions are considered to be at their chemical equilibrium. The reforming pressure is taken equal to 30 bar for all cases. The reactors used for chemical looping have been designed according to two previous works on CLC/CLR with packed bed reactors (Spallina et al., 2017a, 2015a).

2) Acid Gas Removal (AGR): the simulation of acid gas removal is based on amine-based solvent. The reboiler heat duty, the electric consumptions of the pump for solvent circulation, and the specific cost of the complete equipment have been taken from literature (DOE/NETL, 2010; EBTF, 2011; Spallina et al., 2016).

3) $\mathrm{H}_{2}$ purification is carried out in a Pressure Swing Adsorption unit (PSA) for which hydrogen recovery of $89 \%$ is assumed (Spallina et al., 2016).

4) Air Separation Unit (ASU): the ASU has not been modelled, but the mass and energy balances are derived from literature data (Beysel, 2009; Crotti, 2010; Jones et al., 2011; Linde Engineering, n.d.; Smith and Klosek, 2001). The specific energy consumption for the production of oxygen with $95 \%$ purity ranges from $200-300$ $\mathrm{kWh}_{\mathrm{e}} / \mathrm{ton}_{\mathrm{O} 2}$. In this work the specific consumption has been set equal to $250 \mathrm{kWh} /$ ton $_{\mathrm{O} 2}$, corresponding to $0.9 \mathrm{MJ} / \mathrm{kg}_{\mathrm{O} 2}$. The sizing of the ASU is based on the maximum plant capacity available (around $7000 \mathrm{t}_{\mathrm{O} 2} / \mathrm{d}$ per unit, approximately $81 \mathrm{~kg} / \mathrm{s}$ as for the $1 \mathrm{~s}-$ ATR).

5) Turbomachines: the blowers, pumps, compressor, expanders and steam turbine are calculated assuming isentropic and electro-mechanical efficiencies from which the thermodynamic conditions of the outlet streams and the energy balance is derived (Table 1).

6) Heat exchangers are modelled in order to achieve a minimum pinch temperature difference which is assumed equal to $5{ }^{\circ} \mathrm{C}$ (liquid-liquid), $10{ }^{\circ} \mathrm{C}$ (gas-liquid) and $25^{\circ} \mathrm{C}$ (gas-gas).

The comparison has been carried out, using some key technology parameters listed below (eq. 2-12):

$$
\begin{aligned}
& \begin{array}{l}
\text { Equivalent natural gas } \\
\quad \text { flow rate }
\end{array} \dot{m}_{N G, e q}=\dot{m}_{N G}-\frac{W_{e l}}{\eta_{e l, r e f} \cdot L H V_{N G}}-\frac{\dot{Q}_{t h}}{\eta_{t h, r e f} \cdot L H V_{N G}} \\
& \text { Where } \eta_{\text {el }}=0.583 ; \eta_{\text {th }}=0.9 \\
& \text { Steam-to-export } \quad \dot{Q}_{\text {th }}=\dot{m}_{\text {steam }} \cdot\left(h_{s} @ 6 b a r-h_{\text {liq, sat } @ 6 b a r}\right) \\
& \begin{array}{l}
\text { Process Efficiency for } \\
\mathrm{H}_{2}
\end{array} \eta_{\mathrm{H}_{2}}=\frac{\dot{m}_{\mathrm{H}_{2}}{ }^{*} L H V_{\mathrm{H}_{2}}}{\dot{m}_{N G}{ }^{*} L H V_{N G}} \text {; } \\
& \eta_{H_{2, e q}}=\frac{\dot{m}_{H_{2}}{ }^{*} L H V_{H_{2}}}{\dot{m}_{N G, e q}{ }^{*} L H V_{N G}} \\
& \text { Process Efficiency for } \quad \eta_{\mathrm{MeOH}}=\frac{\dot{m}_{\mathrm{MeOH}}{ }^{*} \mathrm{LH} V_{\mathrm{MeOH}}}{\dot{m}_{\mathrm{NG}}{ }^{*} \mathrm{LH} V_{\mathrm{NG}}} \text {; } \\
& \begin{aligned}
\mathrm{MeOH} & \quad \eta_{\mathrm{MeH}}=\frac{m_{\mathrm{MeOH}}{ }^{*} \mathrm{LH} V_{\mathrm{MeOH}}}{\dot{m}_{\mathrm{NG}}^{*} \mathrm{LHV} V_{\mathrm{NG}}} ; \\
& =\frac{\dot{m}_{\mathrm{MeOH}}{ }^{*} \mathrm{LHV} \mathrm{MeOH}}{\eta_{\mathrm{MeOH}}} ;
\end{aligned} \\
& \eta_{\mathrm{MeOH}, \mathrm{eq}}=\frac{\dot{m}_{\mathrm{MeOH}}{ }^{*} \mathrm{LHV} V_{\mathrm{MeOH}}}{\dot{m}_{\mathrm{NGeq}}{ }^{*} \mathrm{LHV} V_{\mathrm{NG}}} \text {; }
\end{aligned}
$$

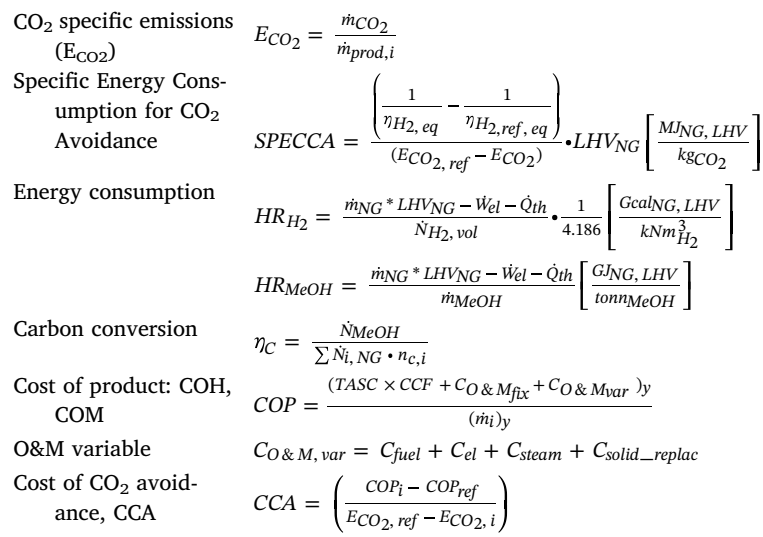

\subsection{Economic model}

The economic analysis is based on the model proposed by DOE (DOE/NETL, 2010, 2011, 2014a) and reported in Table 2.

The cost of the $\mathrm{H}_{2}$ production plant has been derived from (DOE/ NETL, 2010; EBTF, 2011; IEAGHG, 2017; Riva et al., 2018; Spallina et al., 2016). Exponential scaling law has been used to calculate the equipment cost as function of scaling parameters as commonly suggested in the reported in chemical engineering handbook (Sinnott and Towler, 2013; Smith, 1994). The costs are updated to 2018 according to the Chemical Engineering Plant Cost Index, (CEPCI) (Table 3).

The chemical looping reactor network has been designed according to the results of the model as discussed later. Apart from the reactors required to carry out the complete process, two extra units are considered for the purging phase before and after OC oxidation and 25\% more reactor volume is considered in order to have some spare units during maintenance. Each reactor includes high temperature valves for the switching operation. The cost of the reactor is based on the design and costing proposed in the FP7 ASCENT project (http://ascentproject. eu/) and FP7 Democlock project (http://www.sintef.no/Projectweb/ DemoClock/) and published in Mancuso et al. (2017).

The operating costs are derived from the unitary cost of consumables as reported in Table 4.

The comparison is based on the required selling price of the products, and is calculated using the capital charge rate factor (CCF), which defines a characteristic unit cost of the plant per year. This is calculated taking all the expenditures that occur in different periods into account, so that the required return on equity (ROE) equals the internal rate of return (IRR) for plant life time of operation, based on

\begin{tabular}{|c|c|c|c|}
\hline components & $\eta_{\text {is }}$ & $\eta_{\mathrm{m}-\mathrm{e}}$ & Cost reference \\
\hline Blowers & 0.75 & 0.95 & (Manzolini et al., 2006) \\
\hline Compressors & 0.85 & 0.95 & $\begin{array}{l}\text { (Baasel, 1989; Dutch Association of Cost } \\
\text { Engineers, 2014) }\end{array}$ \\
\hline Pumps & 0.85 & 0.95 & $\begin{array}{l}\text { (Baasel, 1989; Dutch Association of Cost } \\
\text { Engineers, 2014) }\end{array}$ \\
\hline Expander & 0.85 & 0.99 & $\begin{array}{l}\text { (Baasel, 1989; Dutch Association of Cost } \\
\text { Engineers, 2014) }\end{array}$ \\
\hline HP Steam Turbine & 0.85 & 0.99 & (Manzolini et al., 2013) \\
\hline LP Steam Turbine & 0.75 & 0.99 & (Manzolini et al., 2013) \\
\hline
\end{tabular}
the assumed financial structure and escalations as reported in Table 5. The resulting CCF are 0.159 and 0.158 respectively for $\mathrm{H}_{2}$ and $\mathrm{MeOH}$ production which is different from the DOE studies due to the different assumptions in the financial model (0.184 for $\mathrm{H}_{2}$ in DOE/NETL (2010) and 0.17 for $\mathrm{MeOH}$ in DOE/NETL (2014a).

Table 1

Main parameters used for the modelling of turbomachines. 
Table 2

Methodology for the calculation of the TASC.

\begin{tabular}{|c|c|c|}
\hline Equipment cost $[\mathrm{EC}]$ of i-component & & M\$ \\
\hline Material cost $[\mathrm{MC}]$ of i-component & & M\$ \\
\hline Labor cost [LC] of i-component & & M\$ \\
\hline Bare Erected Cost $\left[\mathrm{BEC}_{\mathrm{i}}\right]$ of $\mathrm{i}$-component & & M\$ \\
\hline $\mathrm{BEC}=\Sigma \mathrm{BEC}_{\mathrm{i}}$ & & M\$ \\
\hline Engineering procurement and construction [EPC] & $10 \%$ of $\mathrm{BEC}$ & M\$ \\
\hline Contingency $[\mathrm{CON}]$ & $20 \%(B E C+E P C)$ & \\
\hline Total Plant Cost $[\mathrm{TPC}]$ & $\mathrm{BEC}+\mathrm{EPC}+\mathrm{CON}$ & M\$ \\
\hline Owner cost \& other financial cost [O\&OFC] & $20 \%$ of TPC & \\
\hline Total Overnight Cost [TOC] & $\mathrm{TPC}+\mathrm{O \& OFC}$ & \\
\hline Total as spent cost [TASC] & TOC $+18 \%$ & M\$ \\
\hline
\end{tabular}

\section{Chemical Looping packed bed process}

\subsection{Concept}

Chemical looping with packed bed reactors (CL_PB) for natural gas reforming consists of a combination of three conversion units in which gas-solid and catalytic reactions occur (Fig. 1). Compared to the interconnected fluidised bed, this system is dynamically operated. In packed bed gas-solid reactor, the reaction front moves towards the end of the reactor faster and therefore it is possible to accumulate heat inside the reactor (in presence of an exothermic reaction as in the case of oxidation) and then remove the heat by producing high temperature gas for power generation or an endothermic reaction as in the case of steam reforming (Spallina et al., 2019).

In the presence of an OC (e.g. Ni-based), the reactor operated in oxidation converts the $\mathrm{MeO}_{\alpha-1}$ into $\mathrm{MeO}_{\alpha}$ by reaction with air while releasing $\mathrm{N}_{2}$. The reactor operated in reduction, converts the OC to $\mathrm{MeO}_{\alpha-1}$ using low grade fuel available in the plant from downstream processes producing $\mathrm{CO}_{2}$ and $\mathrm{H}_{2} \mathrm{O}$. Finally, a third reactor operated in reforming, where the $\mathrm{OC}$ is in its reduced form, is fed with natural gas together with recirculated $\mathrm{CO}_{2} / \mathrm{H}_{2} \mathrm{O}$ from the reduction phase to convert $\mathrm{CH}_{4}$ into reformed syngas. Some additional dilution is required to increase the $\mathrm{CH}_{4}$ conversion and adjust the $\mathrm{CO} / \mathrm{H}_{2}$ ratio required for the downstream process, however part of the reforming reactants are taken from the reduction outlet. In the case where only $\mathrm{H}_{2} \mathrm{O} / \mathrm{CO}_{2}$ is used, the reformate syngas is richer in $\mathrm{CO}$. This concept has been presented for the first time by the authors in Spallina et al. (2017a) and was also applied to other similar process such as chemical looping switching reforming as proposed in Francisco Morgado et al. (2017) and Zaabout et al. (2019).
Table 4

Assumptions for the calculation of the O\&M costs (DOE/NETL, 2010, 2014a).

\begin{tabular}{|c|c|c|c|}
\hline O\&M -Fixed & & $\mathrm{H}_{2}$ plant & $\mathrm{MeOH}$ plant \\
\hline Labor costs & M\$ & 2.0 & 4.5 \\
\hline Maintenance cost & $\%$ TASC & 0.7 & 0.7 \\
\hline Insurance & $\%$ TASC & 1.5 & 1.6 \\
\hline \multicolumn{4}{|c|}{ Catalyst and sorbent replacement } \\
\hline Oxygen carrier cost & $\$ / \mathrm{kg}$ & 20 & 20 \\
\hline Reforming catalyst cost & $\$ / \mathrm{kg}$ & 50 & 50 \\
\hline Water gas shift catalyst cost & $\$ / \mathrm{kg}$ & 60 & \\
\hline Desulphurization catalyst cost & $\$ / \mathrm{kg}$ & 15 & \\
\hline Methanol synthesis catalyst & $\mathrm{k} \$ / \mathrm{t}$ & & 40 \\
\hline Lifetime catalyst & years & 5 & \\
\hline Lifetime oxygen carriers & years & 2 & \\
\hline \multicolumn{4}{|l|}{ Consumables \& Miscellaneous } \\
\hline Natural gas cost & $\$ / \mathrm{GJ}_{\mathrm{LHV}}$ & 6.5 & \\
\hline Steam cost $\mathrm{t}^{\mathrm{a}}$ & $\$ /$ ton $_{\text {steam }}$ & 0.13 & \\
\hline Electricity cost (generated) & (\$/MWh) & 55 & \\
\hline Electricity cost (purchased & (\$/MWh) & 105 & \\
\hline
\end{tabular}

Table 5

Assumption for the financial model (DOE/NETL, 2010, 2014a; Spallina et al., 2016).

\begin{tabular}{lll}
\hline & $\mathrm{H}_{2}$ plant & $\mathrm{MeOH}$ plant \\
\hline inflation & 0.03 & \\
taxation rate & 0.35 & 30 \\
Depreciation (Year) & 20 & \\
debt interest rate & 0.05 & \\
revenue interest rate & 0.15 & \\
Revenue fraction & 0.4 & 5 \\
Debt fraction & 0.6 & $10 \%$ \\
Construction Payment Years & 3 & $30 \%$ \\
$\rightarrow$ payment 1 st year & $40 \%$ & $25 \%$ \\
$\rightarrow$ payment 2nd year & $30 \%$ & $20 \%$ \\
$\rightarrow$ payment 3rd year & $30 \%$ & $15 \%$ \\
$\rightarrow$ payment 4th year & - & 30 \\
$\rightarrow$ payment 5th year & - & 5 \\
Life time & 20 & \\
Equivalent hrs & 7500 & \\
Construction Years & 3 & \\
\hline
\end{tabular}

- with respect to conventional fired tubular reforming (FTR) plants, the CL_PB process does not require an external furnace and high temperature heat transfer surface, because the process is autothermal;

Table 3

List of reference cost and scale factor used for the calculation of TPC.

\begin{tabular}{|c|c|c|c|c|c|c|c|}
\hline Equipment & Scaling parameter & unit & capacity $_{\text {ref }}$ & $(\mathrm{TPC})_{\mathrm{ref}}, \mathrm{M} \$$ & f & year & Reference \\
\hline Air Separation Unit & oxygen flowrate & $\mathrm{kg} / \mathrm{s}$ & 86 & 636.39 & 0.89 & 2007 & DOE/NETL (2014a) \\
\hline Auto-thermal Reformer including HE and compressors & syngas flowrate & $\mathrm{kmol} / \mathrm{h}$ & 13.73 & 434.60 & 0.82 & 2007 & DOE/NETL (2014a) \\
\hline $\mathrm{MeOH}$ synthesis and separation & $\mathrm{MeOH}$ flow rate & $\mathrm{kg} / \mathrm{s}$ & 115.42 & 397.34 & 0.82 & 2007 & DOE/NETL (2014a) \\
\hline Steam Turbine, large & Net Power & MW & 105 & 85.03 & 0.72 & 2007 & DOE/NETL (2014a) \\
\hline Steam Turbine, small & Net Power & MW & 1.65 & 1.71 & 0.67 & 2017 & DOE/NETL (2010) \\
\hline Cooling plant unit & Heat rejected & $\mathrm{MW}_{\mathrm{th}}$ & 470 & 38.17 & 0.67 & 2017 & \\
\hline BOP & $\mathrm{MeOH}$ flow rate & $\mathrm{kg} / \mathrm{s}$ & 115.42 & 89.97 & 0.67 & 2007 & DOE/NETL (2014a) \\
\hline electric, control and piping & Auxiliary load & MW & 194 & 153.43 & 0.8 & 2007 & DOE/NETL, 2014a \\
\hline Fired Tubular Reforming (including pre-reforming) & Heat of reaction & $\mathrm{MW}_{\text {th }}$ & 245 & 76.35 & 0.67 & 2007 & DOE/NETL, 2010 \\
\hline ZnO sulphur polisher & NG inlet flow rate & $\mathrm{kg} / \mathrm{s}$ & 23.60 & 0.32 & 0.82 & 2007 & DOE/NETL (2010) \\
\hline Air blower & Air flow rate & $\mathrm{kg} / \mathrm{s}$ & 207.51 & 1.14 & 0.72 & 2007 & DOE/NETL, 2010 \\
\hline WGS reactors & Inlet syngas flowrate & $\mathrm{kg} / \mathrm{s}$ & 117.98 & 17.05 & 0.82 & 2007 & DOE/NETL, 2010 \\
\hline MDEA, $\mathrm{CO}_{2}$ separation & $\mathrm{CO}_{2}$ flow rate & $\mathrm{kg} / \mathrm{s}$ & 47.81 & 147.82 & 0.8 & 2007 & DOE/NETL (2010) \\
\hline $\mathrm{MEA}, \mathrm{CO}_{2}$ separation & $\mathrm{CO}_{2}$ flow rate & $\mathrm{kg} / \mathrm{s}$ & 16.44 & 104.99 & 0.8 & 2007 & DOE/NETL (2010) \\
\hline $\mathrm{CO}_{2}$ compressor & Power consumptions & MW & 23.02 & 21.77 & 0.72 & 2007 & DOE/NETL, 2010 \\
\hline PSA & Inlet syngas flowrate & $\mathrm{m}^{3} / \mathrm{s}$ & 4.63 & 50.22 & 1 & 2007 & DOE/NETL, 2010 \\
\hline Gas turbine & Inlet air flow & $\mathrm{kg} / \mathrm{s}$ & 209 & 40.85 & 0.85 & 2007 & DOE/NETL (2014a) \\
\hline syngas coolers & UA & $\mathrm{MW} / \mathrm{K}$ & 1.31 & 2.67 & 0.22 & 2017 & Riva et al. (2018) \\
\hline Chemical looping reactors (including valves, piping, etc.) & Reactor volume & $\mathrm{m}^{3}$ & 261.3 & 11.57 & 1 & 2017 & Mancuso et al. (2017) \\
\hline
\end{tabular}




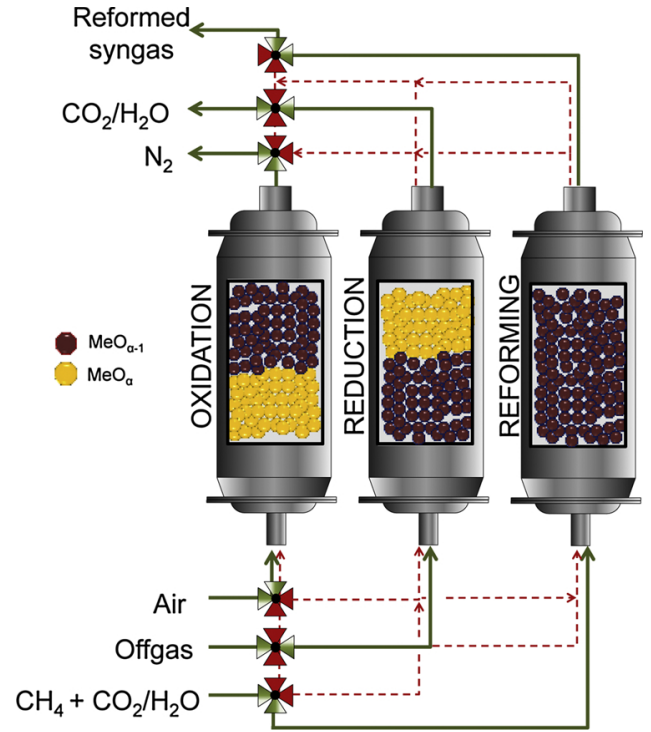

Fig. 1. Schematic of the chemical looping process with PBRs, CL_PB.

- with respect to an ATR process, the oxygen is supplied to the reaction through the OC, therefore a cryogenic air separation unit is not required;

- with respect to the dual-fluidized bed chemical looping reforming, the CL_PB with PBRs can be easily operated at higher pressure. Moreover, intrinsic $\mathrm{CO}_{2}$ separation is achieved in the CL_PB, which delivers a high-pressure $\mathrm{CO}_{2}$ stream without the need of a dedicated process based on amines or other non-commercial technologies as proposed in another work (Ortiz et al., 2011);

- with respect to the integrated reformer with CLC (Pans et al., 2013; Ryden and Lyngfelt, 2006) and all the other mentioned alternative technologies, the steam consumption can be reduced owing to the $\mathrm{CO}_{2} / \mathrm{H}_{2} \mathrm{O}$ recirculation.

\subsection{Model Description}

The model used for the present investigation is based on a 1D adiabatic axially dispersed packed bed reactor model discussed in several previous works from the authors and already validated in two lab scale facilities at Eindhoven University of Technology (Gallucci et al., 2015; Spallina et al., 2017a). The kinetic model is based on the use of $\mathrm{Ni}$ based OC (17-18.5\% wt.) supported on $\mathrm{CaAl}_{2} \mathrm{O}_{4}$ which has been tested and characterised in Medrano et al. (2015). The main model assumptions are: i) no radial profiles; ii) pseudo-homogeneous model; iii) heat losses are negligible due to the large reactor diameter. The governing equations for the reactor model are reported in (Spallina et al., 2017a) including the results for the reactor heat management and operation. The simulation and results for the heat management of the chemical looping reactors for $\mathrm{MeOH}$ production have been updated to the new process configuration (in terms of plant size, gas flowrates, composition and temperature) and therefore presented in 4.3 section while for the chemical looping reactors for $\mathrm{H}_{2}$ production the results were reported in our previous work (Spallina et al., 2017a).

\section{Analysis of Results}

\subsection{Hydrogen production}

The first plant presented in this work is CL_PB in packed beds for $\mathrm{H}_{2}$ production as shown in Fig. 2.

Natural gas (NG, stream \#1) is pre-heated to $280^{\circ} \mathrm{C}$ and sulphur is removed in a $\mathrm{ZnO}$ bed. $\mathrm{NG}$ is then mixed with medium pressure $\mathrm{H}_{2} \mathrm{O}$ from the steam cycle, pre-heated to $580{ }^{\circ} \mathrm{C}$ and mixed with part of the $\mathrm{CO}_{2}-\mathrm{H}_{2} \mathrm{O}$ recirculated from the reduction and finally fed to the reforming reactor (REF, stream \#4). The syngas is then cooled and sent to a high-temperature WGS (at $400^{\circ} \mathrm{C}$ ) to increase the conversion of $\mathrm{CO}$ to $\mathrm{CO}_{2}$ and $\mathrm{H}_{2}$ (\#6). $\mathrm{H}_{2}$ from syngas is then separated at high purity (\#7) in a conventional pressure swing adsorption (PSA). The PSA-offgas is compressed up to 35 bar and mixed with a small amount of $\mathrm{CH}_{4}$ for the reduction process (RED, stream \#9). The resulting gas $\left(72.9 \% \mathrm{CO}_{2}\right.$, $26.4 \% \mathrm{H}_{2} \mathrm{O}, 0.7 \%$ others) is partly fed to the reformer (50\%) in order to dilute the $\mathrm{CH}_{4}$ and increase both the $\mathrm{CO}_{2} / \mathrm{CH}_{4}$ and $\mathrm{H}_{2} \mathrm{O} / \mathrm{CH}_{4}$ ratios. Finally, compressed air (\#13) is sent to the oxidation reactor (OXI) to regenerate the OCs.

The overall mass balance and the main thermodynamic properties of each stream are listed in Table 6.

The energy balance and key performance indicators comparison has been carried out with the state-of-art technologies proposed for $\mathrm{H}_{2}$ production including $\mathrm{CO}_{2}$ capture through solvent processes. The results are shown in Table 7.

In case of $\mathrm{H}_{2}$ production with $\mathrm{CO}_{2}$ capture from flue gas from the

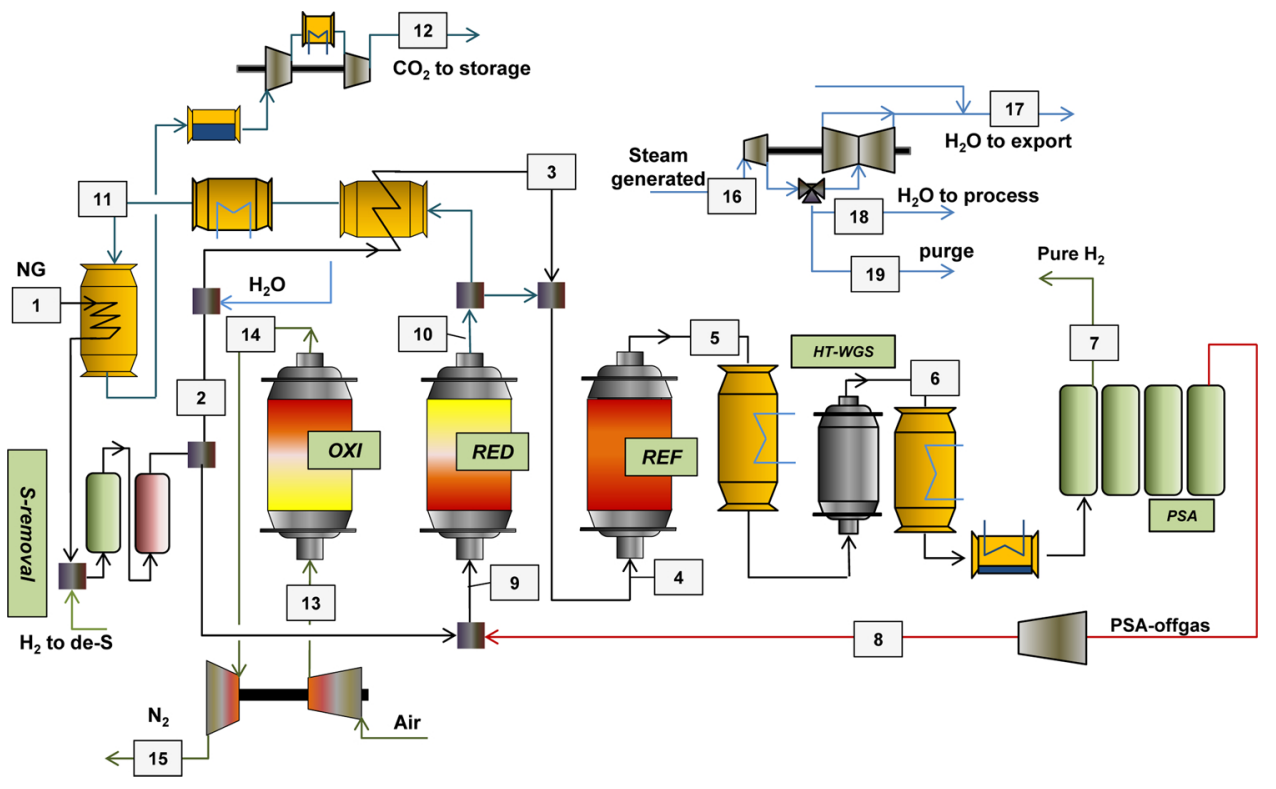

Fig. 2. Integration of chemical looping process for $\mathrm{H}_{2}$ production. 
Table 6

Mass balance of the MeOH-CL_PB plant for $\mathrm{H}_{2}$ production as shown in Fig. 2.

\begin{tabular}{|c|c|c|c|c|c|c|c|c|c|c|c|c|c|}
\hline \multirow[b]{2}{*}{$\# \mathrm{p}$} & \multirow{2}{*}{$\begin{array}{l}\mathrm{p} \\
\text { bar }\end{array}$} & \multirow{2}{*}{$\begin{array}{l}\mathrm{T} \\
{ }^{\circ} \mathrm{C}\end{array}$} & \multirow{2}{*}{$\begin{array}{l}\mathrm{N} \\
\mathrm{kmol} / \mathrm{s}\end{array}$} & \multirow{2}{*}{$\begin{array}{l}\mathrm{m} \\
\mathrm{kg} / \mathrm{s}\end{array}$} & \multirow{2}{*}{$\begin{array}{l}\text { MW } \\
\mathrm{kg} / \mathrm{kmol}\end{array}$} & \multirow[b]{2}{*}{$\mathrm{H}_{2} \mathrm{O}$} & \multicolumn{7}{|c|}{ Composition (\%vol.) } \\
\hline & & & & & & & $\mathrm{N}_{2}$ & $\mathrm{O}_{2}$ & $\mathrm{H}_{2}$ & $\mathrm{CO}$ & $\mathrm{CO}_{2}$ & $\mathrm{CH}_{4}$ & $\mathrm{C}_{2+}$ \\
\hline 1 & 70.0 & 15.0 & 0.15 & 2.62 & 18.02 & & 0.01 & & & & 0.02 & 0.89 & 0.08 \\
\hline 2 & 35.0 & 296.6 & 0.12 & 2.09 & 18.02 & & 0.01 & & & & 0.02 & 0.89 & 0.08 \\
\hline 3 & 30.3 & 580.0 & 0.45 & 8.11 & 17.93 & 0.74 & & & 0.01 & & 0.01 & 0.23 & 0.02 \\
\hline 4 & 30.3 & 699.6 & 0.67 & 16.13 & 24.12 & 0.58 & & & & & 0.24 & 0.15 & 0.01 \\
\hline 5 & 30.0 & 960.0 & 0.91 & 16.13 & 17.75 & 0.35 & & & 0.34 & 0.18 & 0.13 & & \\
\hline 6 & 29.1 & 400.0 & 0.91 & 16.13 & 17.75 & 0.21 & & & 0.47 & 0.05 & 0.26 & & \\
\hline 7 & 29.0 & 31.0 & 0.38 & 0.76 & 2.02 & & & & 1.00 & & & & \\
\hline 8 & 31.6 & 402.1 & 0.33 & 11.86 & 35.58 & & 0.01 & & 0.14 & 0.13 & 0.71 & 0.01 & \\
\hline 9 & 35.0 & 391.5 & 0.36 & 12.39 & 34.16 & & 0.01 & & 0.13 & 0.12 & 0.66 & 0.08 & 0.01 \\
\hline 10 & 31.6 & 937.0 & 0.43 & 16.03 & 37.05 & 0.26 & 0.01 & & & & 0.73 & & \\
\hline 11 & 31.6 & 350.0 & 0.22 & 8.02 & 37.05 & 0.26 & 0.01 & & & & 0.73 & & \\
\hline 12 & 110.0 & 30.0 & 0.16 & 6.99 & 43.88 & & 0.01 & & & & 0.99 & & \\
\hline 13 & 31.6 & 554.2 & 0.54 & 15.62 & 28.85 & & 0.79 & 0.21 & & & & & \\
\hline 14 & 29.6 & 664.5 & 0.46 & 12.48 & 27.41 & 0.06 & 0.94 & & & & & & \\
\hline 15 & 1.0 & 192.3 & 0.46 & 12.48 & 27.41 & 0.06 & 0.94 & & & & & & \\
\hline 16 & 92.0 & 474.5 & 0.66 & 11.82 & 18.02 & 1.00 & & & & & & & \\
\hline 17 & 6.0 & 161.6 & 0.30 & 5.32 & 18.02 & 1.00 & & & & & & & \\
\hline 18 & 40.0 & 358.1 & 0.33 & 6.02 & 18.02 & 1.00 & & & & & & & \\
\hline 19 & 40.0 & 358.1 & 0.03 & 0.49 & 18.02 & 1.00 & & & & & & & \\
\hline
\end{tabular}

furnace $\left(\mathrm{H}_{2}-\mathrm{HCC}\right)$ and syngas $\left(\mathrm{H}_{2}-\mathrm{MCC}\right)$, the same reforming efficiency of the reference reforming plant is achieved $\left(\mathrm{H}_{2}-\mathrm{BC}\right)$. In $\mathrm{H}_{2}$ - $\mathrm{HCC}$, most of the performance drops are associated with the required high consumption of LP steam (the steam from the steam turbine is insufficient) and therefore part of it needs to be imported. The net power production also decreases due to the booster required for the exhaust gas and the $\mathrm{CO}_{2}$ compression. The resulting energy penalty for $\mathrm{CO}_{2}$ capture is $2.56 \mathrm{MJ} / \mathrm{kg}_{\mathrm{CO} 2}$ of primary energy.

In case of partial $\mathrm{CO}_{2}$ separation (from shifted syngas, $\mathrm{H}_{2}-\mathrm{MCC}$ ) only $63.6 \%$ of $\mathrm{CO}_{2}$ is separated, because some NG is still required in the furnace. Despite the reforming efficiency does not changing with respect to the $\mathrm{H}_{2}$-BC case, the efficiency penalty is limited to $73.7 \%$ (compared to $63.6 \%$ of $\mathrm{H}_{2}$-HCC) because of the lower heat consumption for MDEA regeneration and the lower $\mathrm{CO}_{2}$ separation rate. The combination of CCR and energy efficiency results in primary energy consumptions for $\mathrm{CO}_{2}$ avoided of $1.35 \mathrm{MJ} / \mathrm{kg}_{\mathrm{CO} 2}$.

The integration of a chemical looping process for $\mathrm{CO}_{2}$ capture $\left(\mathrm{H}_{2}\right.$ CL_PB) shows a better reforming efficiency than other steam reforming plants (75\% vs $72 \%)$. This is due to the fact that the temperatures of the streams from reduction and oxidation at the outlet of the PBR do not necessarily need to exceed the reforming temperature as is the case in the furnace of the FTR. However, a higher electricity consumption is required to run the entire plant mostly because of the offgas compressor to the reduction reactor. The electricity generated from the gas turbine is overall negative due to the combination of a lower flow rate during expansion than compression (depleted air vs air) and a low turbine inlet temperature with respect to a conventional gas turbine in combined cycle $\left(705^{\circ} \mathrm{C}\right.$ vs $\left.>1300^{\circ} \mathrm{C}\right)$. On the other hand, a larger steam-to-export is obtained due to the high amount of low-temperature heat available in the plant. The $\mathrm{H}_{2}$-CL_PB plant achieves $98 \%$ of $\mathrm{CO}_{2}$ capture rate due to the fact that all the carbon compounds from the PSA (mostly $\mathrm{CO} / \mathrm{CO}_{2}$ and traces of unconverted $\mathrm{CH}_{4}$ ) are converted in the reduction reactor into $\mathrm{CO}_{2}$ and separated downstream except some possible leakage during purge. The overall equivalent reforming efficiency and heat rate results are very close to the one of $\mathrm{H}_{2}-\mathrm{BC}$, and this is also shown by the overall SPECCA of only $0.48 \mathrm{MJ} / \mathrm{kg}_{\mathrm{CO} 2}$.

Table 7

Energy balance and key performance parameters for the selected configurations ( $\mathrm{H}_{2}$ production).

\begin{tabular}{|c|c|c|c|c|c|}
\hline \multicolumn{2}{|l|}{ Hydrogen Production } & \multirow{2}{*}{$\begin{array}{l}\mathrm{H}_{2}-\mathrm{BC} \\
\text { N/A }\end{array}$} & \multirow{2}{*}{$\begin{array}{l}\mathrm{H}_{2} \text {-HCC } \\
\text { MEA flue gas }\end{array}$} & \multirow{2}{*}{$\begin{array}{l}\mathrm{H}_{2} \text {-MCC } \\
\text { MDEA syngas }\end{array}$} & \multirow{2}{*}{$\begin{array}{l}\mathrm{H}_{2} \text {-CL_PB } \\
\text { Chemical Looping }\end{array}$} \\
\hline & & & & & \\
\hline NG flow rate & $\mathrm{kg} / \mathrm{s}$ & 2.62 & 2.62 & 2.62 & 2.62 \\
\hline NG thermal Input & $\mathrm{MW}_{\mathrm{LHV}, \mathrm{NG}}$ & 121.94 & 121.94 & 121.94 & 121.94 \\
\hline $\mathrm{H}_{2}$ mass flowrate & $\mathrm{kg} / \mathrm{s}$ & 0.73 & 0.73 & 0.73 & 0.764 \\
\hline \multicolumn{6}{|l|}{ Electricity prod/cons } \\
\hline Fan/boosters & $\mathrm{MW}_{\mathrm{el}}$ & -0.37 & -0.50 & -0.78 & -5.18 \\
\hline Gas turbine (comp + exp) & $\mathrm{MW}_{\mathrm{el}}$ & & & & -2.97 \\
\hline $\mathrm{CO}_{2}$ compressors & $\mathrm{MW}_{\mathrm{el}}$ & & -2.18 & -1.54 & -0.59 \\
\hline $\mathrm{CO}_{2}$ separation & $\mathrm{MW}_{\mathrm{el}}$ & & -0.05 & -0.04 & \\
\hline Steam Turbine & $\mathrm{MW}_{\mathrm{el}}$ & 3.11 & 3.11 & 3.11 & 3.76 \\
\hline LP/HP pumps & $\mathrm{MW}_{\mathrm{el}}$ & -0.20 & -0.20 & -0.22 & -0.23 \\
\hline other auxiliaries & $\mathrm{MW}_{\mathrm{el}}$ & -0.04 & -0.33 & -0.08 & -0.11 \\
\hline net electric power & $\mathrm{MW}_{\mathrm{el}}$ & 2.50 & -0.14 & 0.45 & -5.35 \\
\hline steam export $\left(160^{\circ} \mathrm{C}, 6\right.$ bar $)$ & $\mathrm{kg} / \mathrm{s}$ & 4.38 & -6.70 & 1.17 & 5.32 \\
\hline Ref. efficiency $\eta_{\mathrm{H} 2}$ & $\mathrm{H}_{2, \mathrm{LHV}} / \mathrm{NG}_{\mathrm{LHV}}$ & $72 \%$ & $72 \%$ & $72 \%$ & $75 \%$ \\
\hline Equivalent NG m $\mathrm{m}_{\mathrm{NG} . e q}$ & $\mathrm{~kg} / \mathrm{s}$ & 2.31 & 2.96 & 2.55 & 2.56 \\
\hline $\mathrm{H}_{2}$ yield & $\mathrm{mol}_{\mathrm{H} 2} / \mathrm{mol}_{\mathrm{NG}}$ & 2.41 & 2.41 & 2.41 & 2.52 \\
\hline Eq. Ref. efficiency $\eta_{\mathrm{H} 2, \mathrm{eq}}$ & $\mathrm{H}_{2, \mathrm{LHV}} / \mathrm{NG}_{\mathrm{eq}, \mathrm{LHV}}$ & $81.5 \%$ & $63.6 \%$ & $73.8 \%$ & $77.1 \%$ \\
\hline Heat Rate & $\mathrm{Gcal} / \mathrm{kNm}_{\mathrm{H} 2}^{3}$ & 3.22 & 3.97 & 3.48 & 3.24 \\
\hline $\mathrm{CO}_{2}$ specific emissions, $\mathrm{E}_{\mathrm{CO} 2}$ & $\mathrm{~kg}_{\mathrm{CO} 2} / \mathrm{kg}_{\mathrm{H} 2}$ & 9.51 & 0.95 & 3.47 & 0.19 \\
\hline $\mathrm{CO}_{2}$ avoided (respect to $\mathrm{H}_{2}-\mathrm{BC}$ ) & $\%$ & $0 \%$ & $90 \%$ & $64 \%$ & $98 \%$ \\
\hline SPECCA (referred to $\eta_{\mathrm{eq}}$ ) & $\mathrm{MJ} / \mathrm{kg}_{\mathrm{CO} 2}$ & & 2.56 & 1.35 & 0.48 \\
\hline
\end{tabular}




\subsection{Cost of hydrogen production}

The economic comparison is reported in Table 8. The $\mathrm{H}_{2}-\mathrm{BC}$ cost is mostly related to the reforming section (55.4\% of the total TPC), and PSA (15\% of TPC). $\mathrm{H}_{2}$-HCC has the highest cost due to the additional $\mathrm{CO}_{2}$ absorption unit which represents more than $50 \%$ of the entire investment cost. Compared to $\mathrm{H}_{2}$-HCC, the $\mathrm{H}_{2}$-MCC has a lower cost of $\mathrm{CO}_{2}$ separation since $\mathrm{CO}_{2}$ is more concentrated in the syngas and only $64 \%$ of $\mathrm{CO}_{2}$ is separated. WGS rectors are more expensive due to the presence of a LT stage. For the given mass and energy balances of $\mathrm{H}_{2}$ CL_PB shown in Table 6, overall 6 reactors are considered of $3.5 \mathrm{~m}$ internal diameter and $10.5 \mathrm{~m}$ length of which 1 reactor is operated respectively in OX/PURGE/RED/REF/PURGE and 1 spare reactor is present in the plant to assist any maintenance issue. In case of $\mathrm{H}_{2}$ CL_PB, the TPC cost is $37 \%$ higher than $\mathrm{H}_{2}-\mathrm{BC}$ but lower than benchmark $\mathrm{CO}_{2}$ capture based technologies, which is related to the fact that the in-situ $\mathrm{CO}_{2}$ separation in the fuel reactor does not add additional cost to the reforming unit. The syngas flow rate, due to the higher $\mathrm{CO}_{2}$ content (26\% vs $13 \%$ after the WGS) is about $30 \%$ higher compared to $\mathrm{H}_{2}$ - $\mathrm{HCC}$ and $\mathrm{H}_{2}$-BC and therefore the cost of WGS reactor and PSA is significantly higher (65\% higher for the WGS and 37\% higher for the PSA with respect to the $\mathrm{H}_{2}$-BC configuration).

Looking at the variable costs, it is important to note that for the benchmark technologies, the only relevant cost is dictated by the natural gas feedstock. Additionally, in the case of $\mathrm{H}_{2}$-CL_PB the cost for the OC replacement and the cost of electricity to be purchased from the network are also relevant in the final annual cost. The cost of OC replacement is mostly influenced by the selected life time ( 2 years) and the price since the analysis is based on a synthetic material.

Overall the cost of hydrogen ( $\mathrm{COH}$ ) for the $\mathrm{H}_{2}$ - $\mathrm{CL}_{-} \mathrm{PB}$ is $30 \%$ higher than the $\mathrm{H}_{2}$ - $\mathrm{BC}$. In terms of cost of $\mathrm{CO}_{2}$ avoidance, the analysis show that the cost $\mathrm{H}_{2}$-CL_PB is $40 \%$ lower than $\mathrm{H}_{2}$ - $\mathrm{HCC}$ and $24 \%$ lower than $\mathrm{H}_{2}$-MCC: in the first case the lower cost of $\mathrm{H}_{2}$ production results from the reduced CCA, while in the second case the higher $\mathrm{CO}_{2}$ capture rate (100\% vs $64 \%)$ makes the chemical-looping technology more advantageous.

Related to the uncertainties on the cost of the novel chemical looping technology, a sensitivity analysis on the $\mathrm{COH}$ and CCA has been carried out by varying the cost of the technology and the OC lifetime and cost. The cost of the technology has been varied from $50 \%$ lower to $300 \%$ higher with respect to the basic scenario.

The lifetime of the OC has been considered respectively from 6 months as the current state-of the-art OC tested in an existing laboratory, up to 5 years which is comparable to the lifetime of commercial catalysts.

The cost of OC has been varied from $2 \$ / \mathrm{kg}$ as in the case of $\mathrm{Fe}_{2} \mathrm{O}_{3}$ -based OC or natural ore such as ilmenite as assumed in DOE/NETL (2014b) and in Mancuso et al. (2017) to $80 \$ / \mathrm{kg}$ which is comparable to the cost of an existing high $\mathrm{Ni}$ content catalyst as experimentally used in Medrano et al. (2015) and Spallina et al. (2017a) or in the scenario of high cost OC.

The results of the sensitivity analysis are shown in Fig. 3 and they all demonstrated that only for the worst case scenarios such as cost of the reactor $>200 \%$, cost of the OC $>50 \$ / \mathrm{kg}$ and OC lifetime $<1$ year, the $\mathrm{H}_{2}$-CL_PB is no longer competitive with the other technologies considered in this study. When combining the best scenarios, the cost of hydrogen production from $\mathrm{H}_{2}$-CL_PB is just $15 \%$ higher than the $\mathrm{H}_{2}-\mathrm{BC}$ and the resulting $\mathrm{CO}_{2}$ avoidance cost drops to $27.05 \$ /$ ton $_{\mathrm{CO} 2}$, which is already convenient in the case of a low carbon tax scenario.

\subsection{Methanol production}

In case of $\mathrm{MeOH}$ production, the chemical looping process is very similar to the one described for $\mathrm{H}_{2}$ production (Fig. 4). In this case, the incondensable gases (\#11) are partly recirculated to the methanol synthesis reactor and partly sent to the reactor operated in reduction
(\#12). A small PSA is used to separate the required $\mathrm{H}_{2}$ for the sulphur treatment of NG. NG pre-heating is carried out using the $\mathrm{CO}_{2}$-rich stream from the fuel reactor and it is mixed first with IP steam from the steam turbine (to achieve a $\mathrm{S} / \mathrm{C}$ ratio of 1.2) and later with recirculated $\mathrm{H}_{2} \mathrm{O} / \mathrm{CO}_{2}$ to preheat the feed to $532{ }^{\circ} \mathrm{C}(\# 3)$ and achieve a final $\mathrm{S} / \mathrm{C}$ of 1.83 ratio and $\mathrm{CO}_{2} / \mathrm{C}$ ratio of 0.37 which is required to generate a

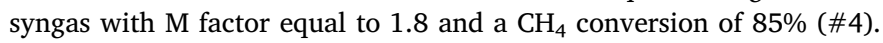
The syngas is cooled to ambient temperature and compressed to $55 \mathrm{bar}$ before being converted in the $\mathrm{MeOH}$ synthesis unit. The $\mathrm{MeOH}$ reactor is cooled producing IP steam. The $\mathrm{MeOH}$-rich stream (\#6) is first separated from the main incondensable gasses through a flash and a first distillation column and later fed to two distillation columns operated at 1.2 bar (feed \#8) and 8.2 bar (feed \#9) to achieve a final purity $>99 \%$.

The design parameters for the heat recovery has been considered the same as for the $\mathrm{H}_{2}$ production plant, therefore HP steam is generated at 92 bar and 485 bar (\#19) and IP steam at 40 bar. LP steam (\#19) at 6 bar is used in the reboilers of the distillation columns and partly for the export. The $\mathrm{CO}_{2} / \mathrm{H}_{2} \mathrm{O}$-rich stream from the reactor(s) operated in reduction is cooled down, $\mathrm{H}_{2} \mathrm{O}$ is separated and the remaining stream is compressed to 110 bar ( $96 \%$ purity due to the presence of some $\mathrm{N}_{2}$ in the NG composition).

About 25\% of incondensables gases are sent to the reduction reactor (\#12). The $\mathrm{CO}_{2} / \mathrm{H}_{2} \mathrm{O}$-rich stream from reduction (\#14) can be varied to meet the desired specification of $\mathrm{M}$ for a proper methanol synthesis and for the NG humidification to avoid carbon deposition.

The overall mass balance and the main thermodynamic properties of each stream are listed in Table 9.

The comparison of the energy balance and performance indicators of the three $\mathrm{MeOH}$ production plants is reported in Table 10. Note that, compared to $\mathrm{H}_{2}$ production, the size of the plant is significantly bigger (approximately 30 times). The $1 \mathrm{~s}$-ATR is more efficient than the $2 \mathrm{~s}$ -

Table 8

Economic comparison for the $\mathrm{H}_{2}$ production configurations.

\begin{tabular}{|c|c|c|c|c|c|}
\hline & & $\mathrm{H}_{2}-\mathrm{BC}$ & $\mathrm{H}_{2}-\mathrm{HCC}$ & $\mathrm{H}_{2}$-MCC & $\mathrm{H}_{2}$-CL_PB \\
\hline Total plant cost, $\times$ item & M\$ & & & & \\
\hline $\begin{array}{l}\text { Fired Tubular Reforming } \\
\quad \text { (including pre-reforming) }\end{array}$ & & 22.76 & 22.76 & 22.44 & \\
\hline Water Gas Shift reactors & & 2.33 & 2.33 & 4.05 & 3.85 \\
\hline ZnO sulphur polisher & & 0.05 & 0.05 & 0.05 & 0.05 \\
\hline Pressure Swing Adsorption & & 6.29 & 6.29 & 5.21 & 8.63 \\
\hline Steam Turbine & & 3.18 & 3.18 & 3.09 & 3.19 \\
\hline Blowers/fan & & 0.24 & 0.24 & 0.23 & 0.06 \\
\hline $\mathrm{CO}_{2}$ compression & & & 4.73 & 3.56 & 1.80 \\
\hline $\mathrm{CO}_{2}$ separation & & & 55.94 & 25.49 & \\
\hline Syngas coolers & & 1.66 & 1.66 & 1.66 & 1.89 \\
\hline $\begin{array}{l}\text { Chemical Looping reactor } \\
\text { network }\end{array}$ & & & & & 26.84 \\
\hline gas turbine & & & & & 5.19 \\
\hline offgas compressor & & & & & 3.58 \\
\hline Heat rejection unit & & 1.67 & 6.82 & 2.70 & 3.36 \\
\hline balance of plant & & 3.59 & 3.59 & 4.95 & 3.39 \\
\hline TPC & M\$ & 41.80 & 107.61 & 73.45 & 61.84 \\
\hline TOC & & 50.16 & 129.13 & 88.14 & 74.21 \\
\hline TASC & & 59.19 & 152.38 & 104.01 & 87.57 \\
\hline $\mathrm{CCF} \times \mathrm{TASC}$ & $\mathrm{M} \$ / \mathrm{y}$ & 9.41 & 24.23 & 16.54 & 13.92 \\
\hline O\&M fixed & $\mathrm{M} \$ / \mathrm{y}$ & & & & \\
\hline labor & & 2.00 & 2.00 & 2.00 & 2.00 \\
\hline maintenance & & 0.07 & 0.17 & 0.12 & 0.10 \\
\hline insurance & & 0.14 & 0.36 & 0.25 & 0.21 \\
\hline O\&M variable & $\mathbf{M} \$ / \mathbf{y}$ & & & & \\
\hline catalysts & & 0.23 & 0.23 & 0.28 & 0.08 \\
\hline oxygen carrier & & & & & 3.24 \\
\hline steam-to-import/export & & 0.02 & -0.02 & & 0.02 \\
\hline electricity & & -1.03 & & -0.02 & 4.21 \\
\hline Natural gas feedstock & & 21.40 & 21.40 & 21.40 & 21.40 \\
\hline & $\mathbf{M} \$ / \mathbf{y}$ & 32.23 & 48.37 & 40.56 & 45.18 \\
\hline \multirow{2}{*}{ cost of hydrogen } & $\$ / \mathrm{kg}$ & 1.63 & 2.45 & 2.06 & 2.19 \\
\hline & $\$ / \mathrm{Nm}^{3}$ & 0.15 & 0.22 & 0.18 & 0.20 \\
\hline cost of $\mathrm{CO}_{2}$ avoidance & \$/ton & 0.00 & 95.58 & 70.64 & 59.87 \\
\hline
\end{tabular}



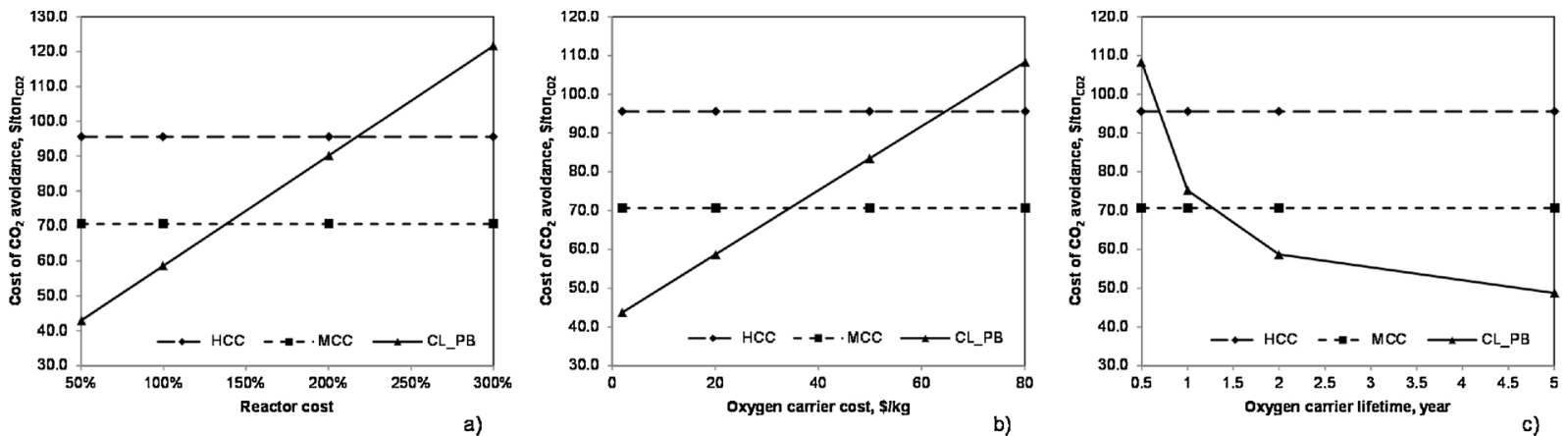

Fig. 3. Sensitivity analysis on the cost of $\mathrm{CO}_{2}$ avoidance for $\mathrm{H}_{2}$ prodcution.

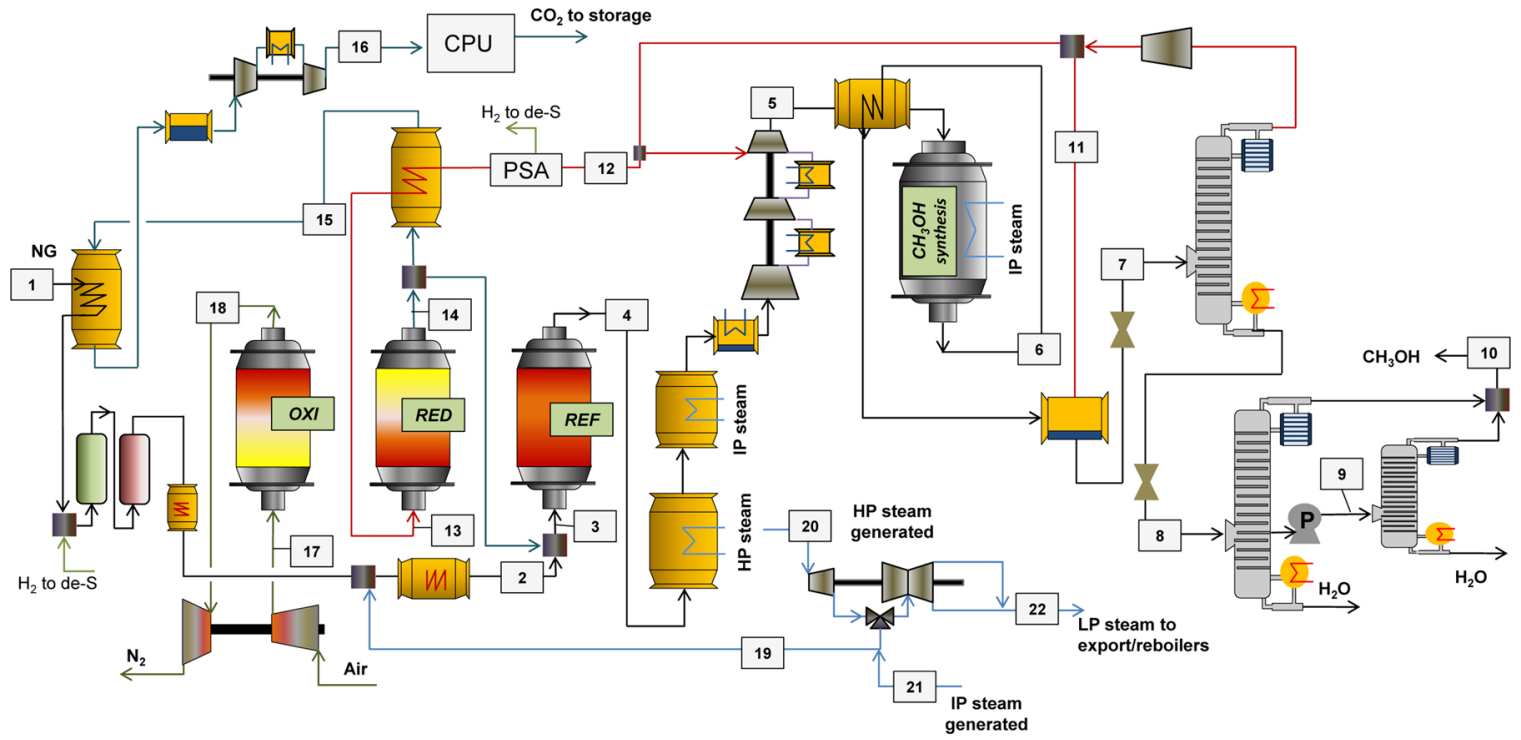

Fig. 4. Integration of chemical looping process for $\mathrm{MeOH}$ production.

Table 9

Mass balance of MeOH-CL_PB production as shown in Fig. 4.

\begin{tabular}{|c|c|c|c|c|c|c|c|c|c|c|c|c|c|c|}
\hline \multirow[b]{2}{*}{$\# \mathrm{p}$} & \multirow{2}{*}{$\begin{array}{l}\mathrm{p} \\
\text { bar }\end{array}$} & \multirow{2}{*}{$\begin{array}{l}\mathrm{T} \\
{ }^{\circ} \mathrm{C}\end{array}$} & \multirow{2}{*}{$\begin{array}{l}\mathrm{N} \\
\mathrm{kmol} / \mathrm{s}\end{array}$} & \multirow{2}{*}{$\begin{array}{l}\mathrm{m} \\
\mathrm{kg} / \mathrm{s}\end{array}$} & \multirow{2}{*}{$\begin{array}{l}\mathrm{MW} \\
\mathrm{kg} / \mathrm{kmol}\end{array}$} & \multirow[b]{2}{*}{$\mathrm{H}_{2} \mathrm{O}$} & \multicolumn{8}{|c|}{ Composition (\%vol.) } \\
\hline & & & & & & & $\mathrm{N}_{2}$ & $\mathrm{O}_{2}$ & $\mathrm{H}_{2}$ & $\mathrm{CO}$ & $\mathrm{CO}_{2}$ & $\mathrm{CH}_{4}$ & $\mathrm{C}_{2+}$ & $\mathrm{CH}_{3} \mathrm{OH}$ \\
\hline 1 & 70.0 & 15.0 & 4.08 & 73.55 & 18.02 & & 0.01 & & & & 0.02 & 0.89 & 0.08 & \\
\hline 2 & 30.6 & 312.6 & 9.38 & 167.65 & 17.88 & 0.56 & & & 0.01 & & 0.01 & 0.39 & 0.04 & \\
\hline 3 & 27.5 & 532.5 & 13.68 & 285.12 & 20.84 & 0.58 & 0.01 & & 0.01 & & 0.12 & 0.27 & 0.02 & \\
\hline 4 & 30.0 & 940.0 & 21.02 & 285.12 & 13.56 & 0.22 & & & 0.49 & 0.19 & 0.06 & 0.03 & & \\
\hline 5 & 56.0 & 56.7 & 32.40 & 424.88 & 13.11 & & 0.01 & & 0.60 & 0.19 & 0.11 & 0.08 & & \\
\hline 6 & 53.2 & 260.0 & 25.33 & 424.88 & 16.77 & 0.01 & 0.01 & & 0.49 & 0.11 & 0.13 & 0.10 & & 0.14 \\
\hline 7 & 2.0 & 11.7 & 4.00 & 127.52 & 31.85 & 0.06 & & & & & 0.06 & & & 0.88 \\
\hline 8 & 2.0 & 83.0 & 3.72 & 116.17 & 31.20 & 0.06 & & & & & & & & 0.94 \\
\hline 9 & 8.2 & 129.0 & 0.03 & 0.66 & 19.72 & 0.88 & & & & & & & & 0.12 \\
\hline 10 & 1.2 & 68.3 & 3.50 & 112.20 & 32.02 & 0.002 & & & & & & & & 0.998 \\
\hline 11 & 53.0 & 15.0 & 16.00 & 223.03 & 13.94 & & 0.02 & & 0.58 & 0.13 & 0.15 & 0.12 & & \\
\hline 12 & 25.0 & 26.6 & 5.61 & 85.68 & 15.27 & & 0.02 & & 0.55 & 0.12 & 0.18 & 0.12 & & 0.01 \\
\hline 13 & 25.0 & 350.0 & 5.53 & 85.51 & 15.46 & & 0.02 & & 0.54 & 0.13 & 0.19 & 0.12 & & 0.01 \\
\hline 14 & 24.2 & 1030.4 & 6.95 & 189.48 & 27.27 & 0.64 & 0.01 & & & & 0.35 & & & \\
\hline 15 & 33.7 & 207.0 & 2.64 & 72.00 & 27.27 & 0.64 & 0.01 & & & & 0.35 & & & \\
\hline 16 & 110.0 & 30.0 & 0.96 & 41.82 & 43.35 & & 0.04 & & & & 0.96 & & & \\
\hline 17 & 25.0 & 466.0 & 15.47 & 446.39 & 28.85 & & 0.79 & 0.21 & & & & & & \\
\hline 18 & 23.2 & 881.6 & 12.22 & 342.42 & 28.01 & & 1.00 & & & & & & & \\
\hline 19 & 40.0 & 342.2 & 5.21 & 93.93 & 18.02 & 1.00 & & & & & & & & \\
\hline 20 & 92.0 & 485.4 & 10.56 & 190.18 & 18.02 & 1.00 & & & & & & & & \\
\hline 21 & 40.0 & 262.7 & 1.27 & 22.81 & 18.02 & 1.00 & & & & & & & & \\
\hline 22 & 6.0 & 159.7 & 13.63 & 245.55 & 18.02 & 1.00 & & & & & & & & \\
\hline
\end{tabular}


Table 10

Energy balance and key performance parameters for the selected configurations for $\mathrm{MeOH}$ production.

\begin{tabular}{|c|c|c|c|c|}
\hline Methanol Production & & 1s-ATR & 2s-ATR & $\begin{array}{l}\text { MeOH-CL_PB } \\
\text { Chemical } \\
\text { Looping }\end{array}$ \\
\hline NG flow rate & $\mathrm{kg} / \mathrm{s}$ & 73.55 & 73.55 & 73.55 \\
\hline NG thermal Input & $\mathrm{MW}_{\mathrm{LHV}, \mathrm{NG}}$ & 3418.67 & 3418.67 & 3418.67 \\
\hline $\mathrm{MeOH}$ flow rate & $\mathrm{kg} / \mathrm{s}$ & 118.34 & 112.46 & 112.20 \\
\hline $\mathrm{MeOH}$ flow rate & TPD & 10224.77 & 9716.66 & 9694.36 \\
\hline \multicolumn{5}{|l|}{ Electricity prod/cons } \\
\hline Fan/boosters & $\mathrm{MW}_{\mathrm{el}}$ & -2.63 & -6.12 & -0.53 \\
\hline $\begin{array}{l}\text { Gas turbine } \\
\qquad(\text { comp }+ \text { exp })\end{array}$ & $\mathrm{MW}_{\mathrm{el}}$ & & & 5.85 \\
\hline syngas compressors & $\mathrm{MW}_{\mathrm{el}}$ & -46.46 & -53.66 & -39.45 \\
\hline Air Separation Unit & $\mathrm{MW}_{\mathrm{el}}$ & -71.50 & -51.13 & \\
\hline $\mathrm{CO}_{2}$ compression & & & & -3.32 \\
\hline Steam Turbine & $\mathrm{MW}_{\mathrm{el}}$ & 67.25 & 115.36 & 103.33 \\
\hline LP/HP pumps & $\mathrm{MW}_{\mathrm{el}}$ & -2.79 & -3.81 & -3.26 \\
\hline oth. Auxiliaries & $\mathrm{MW}_{\mathrm{el}}$ & -3.89 & -3.67 & -3.73 \\
\hline net electric power & $\mathrm{MW}_{\mathrm{el}}$ & -60.02 & -3.03 & 58.89 \\
\hline $\begin{array}{l}\text { steam export }\left(160^{\circ} \mathrm{C} \text {, }\right. \\
6 \text { bar })\end{array}$ & $\mathrm{kg} / \mathrm{s}$ & 91.92 & 54.04 & 67.37 \\
\hline $\mathrm{MeOH}$ efficiency & $\begin{array}{l}\mathrm{MeOH}_{, \mathrm{LHV}} / \\
\mathrm{NG}_{\mathrm{LHV}}\end{array}$ & $79 \%$ & $75 \%$ & $75 \%$ \\
\hline Equivalent NG $\mathrm{m}_{\mathrm{NG} . e q}$ & $\mathrm{~kg} / \mathrm{s}$ & 71.18 & 70.97 & 68.02 \\
\hline Carbon conversion & $\begin{array}{l}\text { mol }_{\mathrm{MEOH}} / \\
\mathrm{mol}_{\mathrm{C}, \mathrm{NG}}\end{array}$ & $80.3 \%$ & $76.4 \%$ & $76.2 \%$ \\
\hline $\begin{array}{l}\text { Eq. Ref. efficiency } \\
\eta_{\mathrm{MEOH,eq}}\end{array}$ & $\begin{array}{l}\mathrm{MeOH}_{\text {,LHV/ }} / \\
\mathrm{NG}_{\text {eq, LHV }}\end{array}$ & $81.2 \%$ & $77.4 \%$ & $80.6 \%$ \\
\hline Heat Rate & $\begin{array}{l}\mathrm{GJ}_{\mathrm{LHV}, \mathrm{NG}} / \\
\text { ton }_{\mathrm{MeOH}}\end{array}$ & 27.77 & 30.43 & 29.94 \\
\hline $\begin{array}{c}\mathrm{CO}_{2} \text { specific emissions, } \\
\mathrm{E}_{\mathrm{CO} 2}\end{array}$ & $\mathrm{~kg}_{\mathrm{CO} 2} / \mathrm{kg}_{\mathrm{MeOH}}$ & 220 & 275 & 6 \\
\hline
\end{tabular}

ATR, mostly because of the higher carbon conversion, which is explained with the higher fuel consumption required in the furnace due to the presence of $\mathrm{N}_{2}$ in the oxidant stream (not present in the 1s-ATR). It is remarkable to notice that the 2s-ATR has lower electricity consumptions $\left(3 \mathrm{MW}_{\mathrm{e}}\right.$ vs $60 \mathrm{MW}_{\mathrm{e}}$ ) mostly due to a lower amount of $\mathrm{O}_{2}$ required for the reforming $(-28.6 \%)$ and a higher electricity production through the steam turbine because a larger amount of high temperature heat is recovered to produce HP steam through the syngas coolers and flue gases. The 2s-ATR has a lower steam-to-export (steam consumption is higher compared to 1 s-ATR). However, the 2s-ATR could represent a favourable solution in case the plant is located in more remote areas, where steam is not valuable, or electricity cost is excessively high.

The $\mathrm{MeOH}$ production efficiency of the $\mathrm{MeOH}-\mathrm{CL}_{-} \mathrm{PB}$ plant is comparable with the 2s-ATR process and lower than the 1s-ATR. Despite the fact that $\mathrm{N}_{2}$ from the oxidation reactor is delivered at high temperature, the overall thermal balance of the reforming section is mitigated by the lower temperatures of the gases at the outlet compared to 1s-ATR and 2s-ATR.

As discussed for the $\mathrm{H}_{2}$-CL_PB process, the gas turbine specific work is very low (compared to a commercial natural gas fuelled gas turbine) related to the operating conditions and therefore the electricity production is modest. The syngas compressor duty in the MeOH-CL_PB is lower compared to the $1 \mathrm{~s}$-ATR and $2 \mathrm{~s}$-ATR, and this is associated with the lower volumetric flow rate because of the higher overall $\mathrm{CH}_{4}$ conversion $(96 \%$ vs $85 \%)$ due to the final temperature in the secondary reforming. In the $\mathrm{MeOH}-\mathrm{CL}_{-} \mathrm{PB}$, the syngas feed of the $\mathrm{MeOH}$ synthesis reactor contains $8 \%$ of $\mathrm{CH}_{4}$ (vol.), whereas in the 1s-ATR the $\mathrm{CH}_{4}$ content is $6.9 \%$, and therefore no relevant effects on the yield of $\mathrm{MeOH}$ is expected, since the $\mathrm{CH}_{4}$ normally does not participate in the reactions.

The ASU represents a large electricity consumption in both the $1 \mathrm{~s}-$ ATR and 2s-ATR configurations due to the large amount of $\mathrm{O}_{2}$ required for the autothermal reforming (respectively 80.8 and $56.8 \mathrm{~kg} / \mathrm{s} \mathrm{of} \mathrm{O}_{2}$ ). The electricity production from the steam turbine of the MeOH-CL_PB process is $103.3 \mathrm{MW}_{\mathrm{e}}$, higher than 1s-ATR (67.2 $\mathrm{MW}_{\mathrm{e}}$ ) and slightly lower than for the 1s-ATR (115.4 MWe). Despite some cost for $\mathrm{CO}_{2}$ compression up to 110 bar $\left(3.3 \mathrm{MW}_{\mathrm{e}}\right.$ ), overall, the $\mathrm{MeOH}-\mathrm{CL}_{-} \mathrm{PB}$ has a net electricity production of $58.9 \mathrm{MW}_{\mathrm{e}}$. In terms of equivalent $\mathrm{MeOH}$ production efficiency, the MeOH-CL_PB is slightly lower than the $1 \mathrm{~s}$ ATR (-0.5 percentage points) and somewhat higher than the 2s-ATR ( +3.3 percentage points). The two ATR configurations show respectively 220 and $275 \mathrm{~kg}_{\mathrm{CO} 2} / \mathrm{ton}_{\mathrm{MeOH}}$, while in the case of the chemicallooping process the emissions are close to zero. In case of MeOH-CL_PB only $2 \%$ of the offgas is assumed to be lost to the atmosphere due to the switching operations resulting in $5.74 \mathrm{~kg}_{\mathrm{CO} 2} / \mathrm{ton}_{\mathrm{MeOH}}$.

For the given mass and energy balances shown in the Table 9, overall 23 reactors are considered of $5.5 \mathrm{~m}$ internal diameter and $13.5 \mathrm{~m}$ length, in which 6 reactors are operated in oxidation, 2 reactors in purge, 4 reactors in reduction, and 6 reactors in reforming, while 5 spare reactors are present in the plant to assist any maintenance issue and ensure that the plant capacity is always higher than $85 \%$. The total amount of oxygen carrier/catalyst required in the reactor is 4705 tons, which is assumed to be replaced every 2 years corresponding to the assumed OC lifetime. Therefore, compared to the 1s-ATR, the amount of material/catalyst required for the $\mathrm{MeOH}-\mathrm{CL}_{-} \mathrm{PB}$ is 14.2 times more.

The chemical-looping process behaviour has been simulated for the given geometry and feed composition. Two cases have been considered: case (a) the OC active content is $3 \%$ and case (b) the OC active weight content is $20 \%$ ( $\mathrm{Ni}$ supported on $\mathrm{CaAl}_{2} \mathrm{O}_{4}$ ). Increasing the $\mathrm{Ni}$ content in the $\mathrm{OC}$ increases the oxygen capacity of each single reactor and therefore, for given inlet conditions and reactor volume, the cycle time is longer and amounts respectively $550 \mathrm{~s}$ for case (a) and 1700 s for case (b). In Fig. 5, the expected gas composition and gas temperature of the streams at the reactor outlets are shown for the two cases.

The case with the low $\mathrm{Ni}$ content (case a) does not exhibit relevant variations in the outlet temperature and it behaves effectively as a
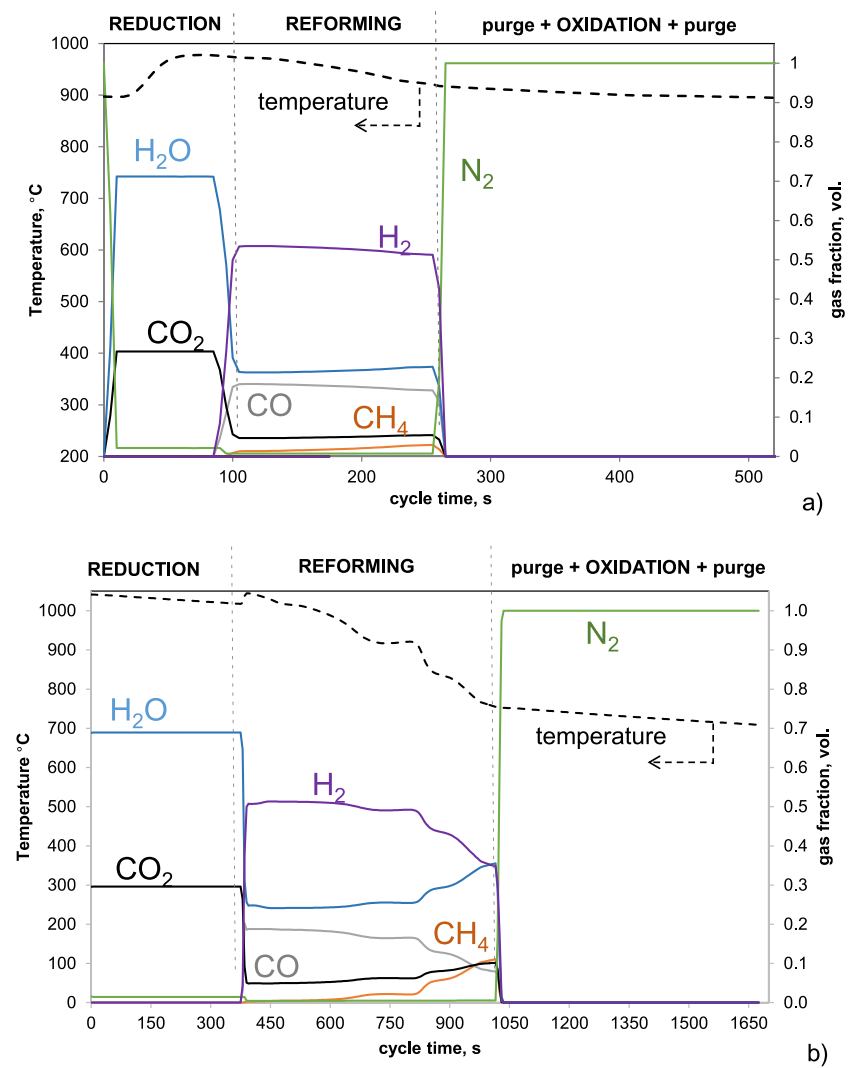

Fig. 5. Gas conditions at the reactor outlet during the CLR in PBR using 3\%wt. of $\mathrm{NiO}$ (over $\mathrm{CaAl}_{2} \mathrm{O}_{4}$ ) as for case (a) and $20 \%$ wt. of $\mathrm{NiO}$ (over $\mathrm{CaAl}_{2} \mathrm{O}_{4}$ ) as for case (b). 
pseudo-steady state process, which is very beneficial from an operational point of view of the downstream process units. Moreover, the low $\mathrm{Ni}$ content could be beneficial for the OC lifetime/cost, particularly since this material is subjected to a low temperature difference over the cycle, approximately $100^{\circ} \mathrm{C}$ for case (a), compared to about $400{ }^{\circ} \mathrm{C}$ for case (b). The dependence of the temperature rise on the $\mathrm{OC}$ composition has already been investigated and demonstrated in Noorman et al. (2007).

For case (a), the reactor unit (pressure vessel, high temperature valves and additional piping) may be subjected to excessive mechanical stress due to fatigue because of the short cycle time. This issue does probably not justify the use of a low OC content, however this decision is related to a specific appraisal in terms of reactor and process engineering, and the trade-off between cost of the reactor, cost of the OC, and control operation for a batch-based process.

For case (b), the authors have already demonstrated in Spallina et al. (2017a, 2015a,b) that the temperature of the gases and its fluctuation can be smoothed by operating multiple reactors which are carrying the same phase in parallel but with a phase displacement, as shown for the MeOH-CL_PB configuration in Fig. 6. This control strategy is beneficial for the other downstream processes because the flow rate, composition and temperature do not exhibit fluctuations after mixing as shown in Fig. 7: the temperature of the gas after oxidation and the products of reduction is almost constant $\left( \pm 6^{\circ} \mathrm{C}\right)$ while during the reforming there is a maximum temperature variation of only $40^{\circ} \mathrm{C}$ over the entire cycle. This fluctuation is also slightly changing the expected stoichiometric $\mathrm{M}$ factor (as reported in equation 1), which is however within the desired range for more than $90 \%$ of the entire cycle.

\subsection{Cost of methanol production}

The economic analysis for the $\mathrm{MeOH}$ production is reported in Table 11. The overall TPC of the 1s-ATR and 2s-ATR is mostly represented by the cost of the syngas generation (respectively $25.2 \%$ and $39 \%$ of the total TPC) and the ASU (respectively 34.2 and $23.9 \%$ of the TPC). The other main units of the entire plant are very similar in terms of equipment and installation costs. Overall the TPC of the 2 s-ATR is $5 \%$ higher than the $1 \mathrm{~s}$-ATR which is slightly lower than the difference estimated by Haldor Tropsøe $(+18 \%$ as reported in Kim Aasberg-Petersen et al. (2013)). This is partly explained by the fact that in the reference considered, the 2s-ATR configuration is assessed as 2 parallel syngas generation units of 5,000 TPD each while the 1s-ATR is one large unit of 10,000 TPD. Overall the costs are in line with the study published from the NETL (DOE/NETL, 2014a) about the baseline plant for $\mathrm{MeOH}$ production from which most of the cost database has been taken.

For the 1s-ATR and 2s-ATR the annual fixed and variable O\&M costs

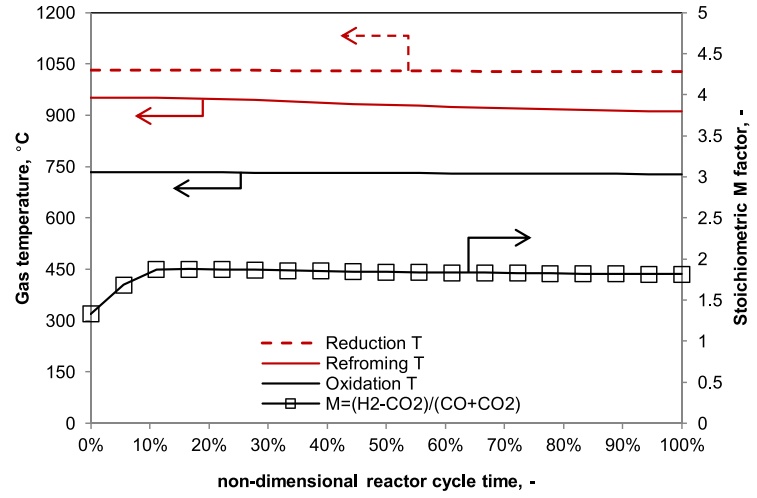

Fig. 7. Gas conditions chemical looping reactor outlet after mixing the streams coming from parallel reactors.

are mostly dictated by the cost of feedstock ( $47 \%$ of the total annual cost) and the main difference is the cost of electricity to import which is significantly higher for the 1s-ATR, as expected from the overall energy balance shown in Table 10. The final cost for $\mathrm{MeOH}$ generation ranges between 370 and $380 \$ /$ ton $_{\mathrm{MeOH}}$ (the 2s-ATR is $+4 \%$ higher) showing that two technologies are competitive.

In case of $\mathrm{MeOH}-\mathrm{CL}_{-} \mathrm{PB}$, the economic analysis shows a significantly lower TPC (-44\% compared to 1s-ATR). The major reason is the absence of the ASU and a lower cost of the reactor network compared to the reforming section in the ATR plants. The overall chemical looping process including gas turbine, heat exchanger network, syngas compressor is $426 \mathrm{M} \$$ (about 17\% lower than 1s-ATR) Also the BOP costs are lower due to the reduced auxiliary load. The fixed O\&M mostly differ for the insurance which is calculated as fraction of the TASC. The cost for OC replacement has a relevant impact on the O\&M variable cost, which is partly compensated by selling the additional electricity generated from the plant. Overall, the final cost of $\mathrm{MeOH}$ production is $304 \$ /$ ton ( $>17.5 \%$ lower than the ATR plants). Due to the combination of lower $\mathrm{CO}_{2}$ emissions and lower $\mathrm{MeOH}$ cost of production, the resulting CCA is very negative (-303.1 $\$ /$ ton $\left._{\mathrm{CO} 2}\right)$, which means that this plant is already economically attractive, regardless the cost associated to separate and compress the $\mathrm{CO}_{2}$. Such negative price suggests considering business case-based CCUS processes, especially due to the fact that the $\mathrm{CO}_{2}$ is delivered at high purity ( $>96 \%$ ) and overall the process presents a net production of electricity. The integration of a $\mathrm{MeOH}$ plant with a CCUS process will be investigated in a future work.

A sensitivity analysis has been carried out on the price of $\mathrm{MeOH}$ and CCA varying the cost of the chemical-looping reactors, the OC cost and lifetime and also the cost of generated electricity (from 0 to 105

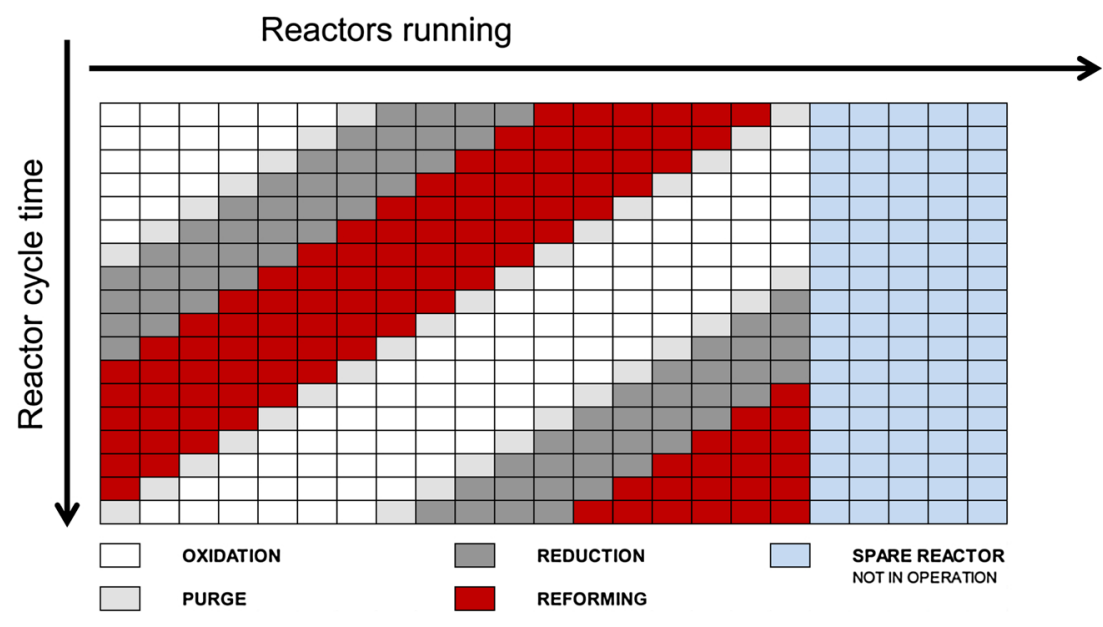

Fig. 6. Reactor operation startegy for $\mathrm{MeOH}$ production. 
Table 11

Economic comparison of the $\mathrm{MeOH}$ production configurations.

\begin{tabular}{|c|c|c|c|c|}
\hline & & 1S-ATR & 2s-ATR & $\begin{array}{l}\text { MeOH- } \\
\text { CL_PB }\end{array}$ \\
\hline Total plant cost, $\times$ item & M\$ & & & \\
\hline $\begin{array}{l}\text { Auto-thermal } \\
\text { reforming }+\mathrm{SC}+\text { syngas } \\
\text { compressor }\end{array}$ & & 512.64 & 707.74 & \\
\hline $\begin{array}{l}\text { Fired Tubular } \\
\quad \text { reforming }+ \text { pre-reforming }\end{array}$ & & & 122.58 & \\
\hline Air Separation Unit & & 694.85 & 507.86 & \\
\hline Methanol synthesis and separation & & 468.11 & 448.95 & 448.10 \\
\hline ZnO sulphur polisher & & 0.94 & 0.94 & 0.94 \\
\hline PSA & & 40.15 & 18.42 & 2.07 \\
\hline Steam Turbine & & 43.31 & 63.87 & 59.01 \\
\hline Blowers/fan & & 0.97 & 1.78 & 0.45 \\
\hline $\mathrm{CO}_{2}$ compression & & & & 6.23 \\
\hline Syngas coolers & & & & 5.62 \\
\hline Chemical Looping reactor network & & & & 311.15 \\
\hline gas turbine & & & & 89.71 \\
\hline offgas compressor & & & & 20.11 \\
\hline Heat rejection unit & & 35.85 & 35.58 & 36.01 \\
\hline balance of plant & & 231.98 & 221.33 & 158.80 \\
\hline Total Plant Cost, TPC & M\$ & 2028.81 & 2129.04 & 1138.19 \\
\hline Total Overnight Cost, TOC & & 2434.57 & 2554.85 & 1365.82 \\
\hline Total As Spent Cost, TASC & & 2872.79 & 3014.72 & 1611.67 \\
\hline $\mathrm{CCF} \times \mathrm{TASC}$ & $\mathrm{M} \$ / \mathrm{y}$ & 456.77 & 479.34 & 256.26 \\
\hline O\&M fixed & $\mathbf{M} \$ / \mathbf{y}$ & & & \\
\hline labour & & 4.50 & 4.50 & 4.50 \\
\hline maintenance & & 20.11 & 21.10 & 11.28 \\
\hline insurance & & 45.96 & 48.24 & 25.79 \\
\hline O\&M variable & $\mathbf{M} \$ / \mathbf{y}$ & & & \\
\hline catalysts & & 4.06 & 5.72 & 0.74 \\
\hline oxygen carrier & & & & 47.04 \\
\hline steam-to-import/export & & 0.21 & 0.01 & -0.21 \\
\hline electricity & & 47.26 & 1.25 & -24.29 \\
\hline Natural gas feedstock & & 599.98 & 599.98 & 599.98 \\
\hline total annual cost & $\mathbf{M} \$ / \mathbf{y}$ & 1178.86 & 1160.14 & 921.08 \\
\hline cost of Methanol & $\$ /$ ton & 368.94 & 382.07 & 304.04 \\
\hline $\begin{array}{l}\text { cost of } \mathrm{CO}_{2} \text { avoidance (respect to } \\
\text { 1s-ATR) }\end{array}$ & $\$ /$ ton $_{\mathrm{CO} 2}$ & - & - & -303.10 \\
\hline
\end{tabular}
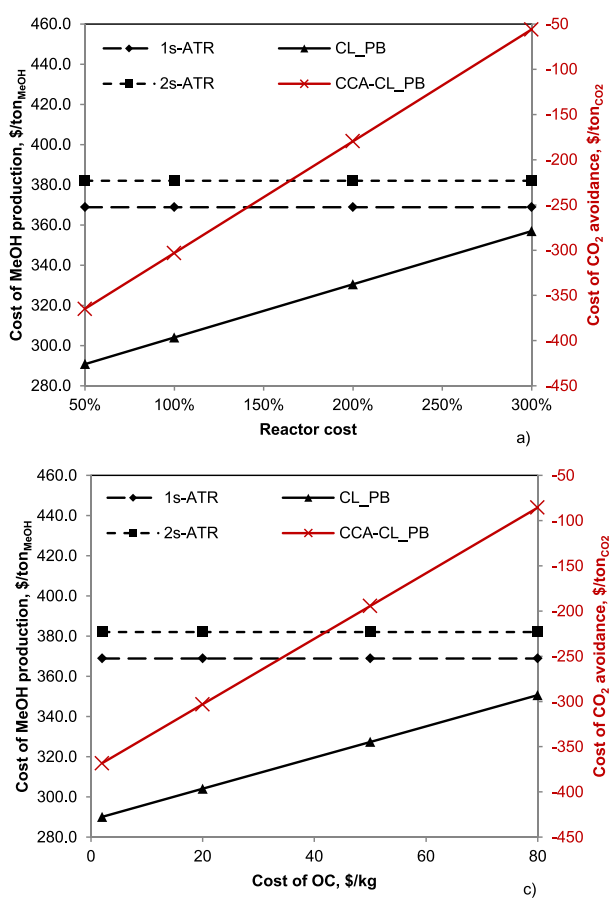

\$/MWh). The results of the sensitivity analysis are shown in Fig. 8. The cost of $\mathrm{MeOH}$ production is always lower than the ATR configurations approaching $356.98 \$ /$ ton in the worst-case scenario for the reactor network costs with a resulting cost of $\mathrm{CO}_{2}$ avoidance of $-55.8 \$ /$ ton $_{\mathrm{CO} 2}$. In the case of combined high reactor cost $(+300 \%)$ and low OC lifetime (1 year), the MeOH-CL_PB results are similar to those of the 1s-ATR (368.94 vs $372.5 \$ /$ ton $\mathrm{MeOH}$ ) with a CCA of $16.6 \$ /$ ton $_{\mathrm{CO} 2}$.

\section{Conclusions}

The current paper has discussed the techno-economic advantages of integrating dynamically operated packed bed reactors in a chemicallooping-based process for the production of $\mathrm{H}_{2}$ and $\mathrm{MeOH}$ with respect to state-of-the-art technologies.

In case of $\mathrm{H}_{2}$ production, the chemical-looping based process is more advantageous than solvent-based technologies for $\mathrm{CO}_{2}$ capture showing a minimal energy penalization and lower $\mathrm{CO}_{2}$ avoidance cost ranging from 17-35\% lower. In a long-term optimal scenario, the cost of $\mathrm{CO}_{2}$ avoidance could reach potentially a low cost $\left(<30 \$ /\right.$ ton of $\left.\mathrm{CO}_{2}\right)$, if the OC cost and lifetime would improve significantly compared to the current technology readiness level, as well as the design and the cost of the reactor network including all the auxiliary equipment such as valves and piping.

In case of $\mathrm{MeOH}$ production the chemical-looping based process presents only a slightly lower efficiency than the conventional technology due to a lower $\mathrm{MeOH}$ production rate, but higher than the twostage reforming process because of the higher energy recovery. In terms of economics, the chemical-looping-based process is more attractive than competing technologies mostly because of the significantly lower plant costs due to the absence of the air separation unit. For $\mathrm{MeOH}$ production with the chemical-looping based process, the separation and compression units do not affect the final cost of the $\mathrm{MeOH}$ production, which results in about $17-20 \%$ lower costs than for the conventional cases. The combination of low $\mathrm{CO}_{2}$ emissions and the low price of $\mathrm{MeOH}$ makes the cost of $\mathrm{CO}_{2}$ avoidance negative, which could lead to a convenient business case for $\mathrm{CO}_{2}$ utilisation.

The results of this work have identified the techno-economic and environmental advantages of a new chemical looping technology for
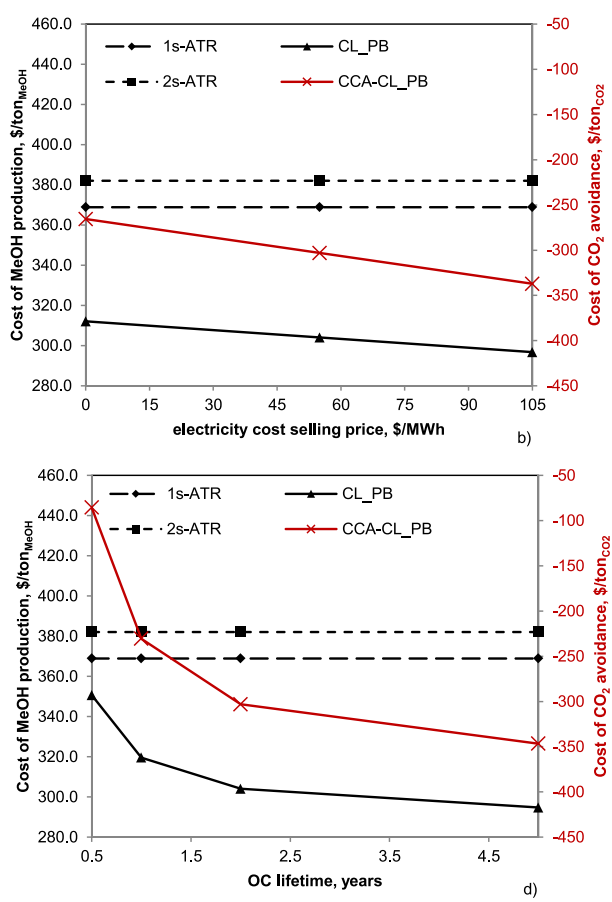

Fig. 8. Sensitivity analysis on the cost of $\mathrm{CO}_{2}$ avoidance and the cost of $\mathrm{MeOH}$ production. 
the production of $\mathrm{H}_{2}$ and $\mathrm{MeOH}$. Despite the very promising results further investigations are required to move toward the implementation and commercialisation of this technology. From a material point of view, more research should be carried out to further improve the stability and life time of the OC, preferrably with lower costs metals that are environmentally benign low-cost, safe and stable than the current Ni-based OC. The experimental demonstration of the technology at larger scales as well as the full process operation and control would help to solve the existing technical challenges due to the dynamic operation and overall cost reduction of the technology. However, the expected performance presented in this work clearly justifies the research efforts required in the scale-up of this technology.

\section{References}

Aasberg-Petersen, K., Christensen, T.S., Nielsen, C.S., Dybkjær, I., 2003. Recent developments in autothermal reforming and pre-reforming for synthesis gas production in GTL applications. Fuel Process. Technol. 83, 253-261. https://doi.org/10.1016/ S0378-3820(03)00073-0.

Abanades, J.C., Wiley, D.E., Li, H., Ho, M.T., Mangano, E., Brandani, S., 2015. Emerging CO2 capture systems. Int. J. Greenh. Gas Control 40, 126-166. https://doi.org/10. 1016/j.ijggc.2015.04.018.

Adanez, J., Abad, A., Garcia-Labiano, F., Gayan, P., de Diego, L., 2012. Progress in Chemical-Looping Combustion and Reforming technologies. Prog. Energy Combust. Sci. 38, 215-282. https://doi.org/10.1016/j.pecs.2011.09.001.

Adánez, J., Abad, A., Mendiara, T., Gayán, P., de Diego, L.F., García-Labiano, F., 2018. Chemical looping combustion of solid fuels. Prog. Energy Combust. Sci. 65, 6-66. https://doi.org/10.1016/j.pecs.2017.07.005.

Appl, M., 2006. Ammonia. Ullmann's Encycl. Ind. Chem. pp. 153. https://doi.org/10. 1002/14356007.a02 143.

Baasel, W.D., 1989. Preliminary Chemical Engineering Plant Design. Van Nostrand Reinhold, New York.

Beysel, G., 2009. Enhanced Cryogenic Air Separation A proven Process applied to Oxyfuel: Future Prospects. 1st Oxyfuel Combustion Conference.

Cheng, W.-H., Kung, H.H., 1994. Methanol production and use. CRC Presshttps://doi.org/ 10.5860/CHOICE.32-3898.

Collodi, G., Azzaro, G., Ferrari, N., Santos, S., 2017. Techno-economic Evaluation of Deploying CCS in SMR Based Merchant H2 Production with NG as Feedstock and Fuel. Energy Procedia 114, 2690-2712. https://doi.org/10.1016/j.egypro.2017.03. 1533.

Crotti, G., 2010. Analisi di unitá criogeniche per il frazionamento dell'aria. Politecnico di Milano.

de Diego, L.F., Ortiz, M., García-Labiano, F., Adánez, J., Abad, A., Gayán, P., 2009d. Hydrogen production by chemical-looping reforming in a circulating fluidized bed reactor using Ni-based oxygen carriers. J. Power Sources 192, 27-34. https://doi. org/10.1016/j.jpowsour.2008.11.038.

DOE/NETL, 2014a. Baseline Analysis of Crude Methanol Production from Coal and Natural Gas.

DOE/NETL, 2014b. Guidance for NETL's Oxycombustion R\&D program: Chemical Looping Combustion Reference Plant Designs and Sensitivity Studies.

DOE/NETL, 2011. Cost and Performance Baseline for Fossil Energy Plants Volume 2: Coal to Synthetic Natural Gas and Ammonia. https://doi.org/DOE/NETL-2010/1402.

DOE/NETL, 2010. Assessment of Hydrogen Production with CO2 Capture Volume 1: Baseline State-of- the-Art Plants.

Dutch Association of Cost Engineers, 2014. Price Booklet edition nr. 30, 30th ed. Michael Sprong.

EBTF, 2011. European best practice guidelines for assessment of CO2 capture technologies.

Fernandez, E., Helmi, A., Medrano, J.A., Coenen, K., Arratibel, A., Melendez, J., de Nooijer, N.C.A., Spallina, V., Viviente, J.L., Zuñiga, J., van Sint Annaland, M., Pacheco Tanaka, D.A., Gallucci, F., 2017. Palladium based membranes and membrane reactors for hydrogen production and purification: An overview of research activities at Tecnalia and TU/e. Int. J. Hydrogen Energy 42. https://doi.org/10.1016/ j.ijhydene.2017.03.067.

Fiedler, E., Grossmann, G., Kersebohm, D., Weiss, G., Witte, C., 2000. Methanol. In: KgaA, W.-V.V.G. C. (Ed.), Ullman's Encyclopedia of Industrial Chemistry.

Fosheim, J.R., Hathaway, B.J., Davidson, J.H., 2018. High efficiency solar chemicallooping methane reforming with ceria in a fixed-bed reactor. Energy 169, 597-612. https://doi.org/10.1016/j.energy.2018.12.037.

Francisco Morgado, J., Cloete, S., Morud, J., Gurker, T., Amini, S., 2017. Modelling study of two chemical looping reforming reactor configurations: looping vs. switching. Powder Technol. 316, 599-613. https://doi.org/10.1016/j.powtec.2016.11.059.

Gallucci, F., Hamers, H.P., van Zanten, M., van Sint Annaland, M., 2015. Experimental demonstration of chemical-looping combustion of syngas in packed bed reactors with ilmenite. Chem. Eng. J. 274, 156-168. https://doi.org/10.1016/j.cej.2015.03.081.

Hamers, H.P., Romano, M.C., Spallina, V., Chiesa, P., Gallucci, F., van Sint Annaland, M. 2015. Boosting the IGCLC process efficiency by optimizing the desulfurization step. Appl. Energy 422-432.

Haussinger, P., Lohmuller, R., Watson, A.M., 2012. Hydrogen. In: 2. Production Wiley (Ed.), Ullman's Encyclopedia of Industrial Chemistry, pp. 249-298. https://doi.org/ 10.1002/14356007.013.
IEA, 2015. Technology Roadmap: Energy and GHG Reductions in the Chemical Industry via Catalytic Processes.

IEAGHG, 2017. Techno - Economic Evaluation of SMR Based Standalone (Merchant) Hydrogen Plant with CCS.

Jones, D., Bhattacharyya, D., Turton, R., Zitney, S.E., 2011. Optimal design and integration of an air separation unit (ASU) for an integrated gasification combined cycle (IGCC) power plant with CO2 capture. Fuel Process. Technol. 92, 1685-1695. https://doi.org/10.1016/j.fuproc.2011.04.018.

Kathe, M.V., Empfield, A., Na, J., Blair, E., Fan, L.S., 2016. Hydrogen production from natural gas using an iron-based chemical looping technology: Thermodynamic simulations and process system analysis. Appl. Energy 165, 183-201. https://doi.org/ 10.1016/j.apenergy.2015.11.047.

Khan, M.N., Shamim, T., 2016. Techno-economic assessment of a plant based on a three reactor chemical looping reforming system. Int. J. Hydrogen Energy 41, 22677-22688. https://doi.org/10.1016/j.ijhydene.2016.09.016.

Aasberg-Petersen, Kim, Charlotte Stub Nielsen, Ib, Dybkjær, Jens Perregaard, 2013. Large Scale Methanol Production from Natural Gas.

Krenzke, P.T., Fosheim, J.R., Davidson, J.H., 2017. Solar fuels via chemical-looping reforming. Sol. Energy 156, 48-72. https://doi.org/10.1016/j.solener.2017.05.095.

Linde Engineering, 2019. Tonnage air separation plants. n.d..

Luo, M., Yi, Y., Wang, S., Wang, Z., Du, M., Pan, J., Wang, Q., 2018. Review of hydrogen production using chemical-looping technology. Renew. Sustain. Energy Rev. 81, 3186-3214. https://doi.org/10.1016/j.rser.2017.07.007.

Mancuso, L., Cloete, S., Chiesa, P., Amini, S., 2017. Economic assessment of packed bed chemical looping combustion and suitable benchmarks. Int. J. Greenh. Gas Control 64, 223-233. https://doi.org/10.1016/j.ijggc.2017.07.015.

Manzolini, G., Dijkstra, J.W., Macchi, E., Jansen, D., 2006. Technical Economic Evaluation of a system for electricity production $\mathrm{CO} 2$ capture using membrane reformer with permeate side combustion. ASME Turbo Expo 2006 1-11.

Manzolini, G., Macchi, E., Gazzani, M., 2013. CO2 capture in natural gas combined cycle with SEWGS. Part B: Economic assessment. Int. J. Greenh. Gas Control 12, 502-509. https://doi.org/10.1016/j.ijggc.2012.06.021.

Martínez, I., Romano, M.C., Chiesa, P., Grasa, G., Murillo, R., 2013. Hydrogen production through sorption enhanced steam reforming of natural gas: Thermodynamic plant assessment. Int. J. Hydrogen Energy 38, 15180-15199. https://doi.org/10.1016/j ijhydene.2013.09.062.

Martini, M., van den Berg, A., Gallucci, F., van Sint Annaland, M., 2016. Investigation of the process operability windows for $\mathrm{Ca}-\mathrm{Cu}$ looping for hydrogen production with $\mathrm{CO} 2$ capture. Chem. Eng. J. 303, 73-88. https://doi.org/10.1016/j.cej.2016.05.135.

Mattisson, T., Keller, M., Linderholm, C., Moldenhauer, P., Rydén, M., Leion, H., Lyngfelt, A., 2018. Chemical-looping technologies using circulating fluidized bed systems: Status of development. Fuel Process. Technol. 172, 1-12. https://doi.org/10.1016/j. fuproc.2017.11.016.

Medrano, J. a., Spallina, V., van Sint Annaland, M., Gallucci, F., 2014. Thermodynamic analysis of a membrane-assisted chemical looping reforming reactor concept for combined H2 production and CO2 capture. Int. J. Hydrogen Energy 39, 4725-4738. https://doi.org/10.1016/j.ijhydene.2013.11.126.

Medrano, J.A., Hamers, H.P., Williams, G., van Sint Annaland, M., Gallucci, F., 2015. $\mathrm{NiO} / \mathrm{CaAl} 2 \mathrm{O} 4$ as active oxygen carrier for low temperature chemical looping applications. Appl. Energy 158, 86-96. https://doi.org/10.1016/j.apenergy.2015.08.078.

Medrano, J.A., Potdar, I., Melendez, J., Spallina, V., Pacheco-Tanaka, D.A., van Sint Annaland, M., Gallucci, F., 2018. The membrane-assisted chemical looping reforming concept for efficient H2production with inherent CO2capture: Experimental demonstration and model validation. Appl. Energy 215, 75-86. https://doi.org/10. 1016/j.apenergy.2018.01.087.

Molburg, J.C., Doctor, R.D., 2003. Hydrogen from Steam-Methane Reforming with CO2 Capture Hydrogen from Steam-Methane Reforming with CO2 Capture.

Muradov, N.Z., Veziroğlu, T.N., 2005. From hydrocarbon to hydrogen-carbon to hydrogen economy. Int. J. Hydrogen Energy 30, 225-237. https://doi.org/10.1016/j. ijhydene.2004.03.033.

Nadgouda, S.G., Guo, M., Tong, A., Fan, L.S., 2019. High purity syngas and hydrogen coproduction using copper-iron oxygen carriers in chemical looping reforming process. Appl. Energy 235, 1415-1426. https://doi.org/10.1016/j.apenergy.2018.11. 051.

Nandy, A., Loha, C., Gu, S., Sarkar, P., Karmakar, M.K., Chatterjee, P.K., 2016. Present status and overview of Chemical Looping Combustion technology. Renew. Sustain. Energy Rev. 59, 597-619. https://doi.org/10.1016/j.rser.2016.01.003.

Nazir, S.M., Morgado, J.F., Bolland, O., Quinta-Ferreira, R., Amini, S., 2018. Technoeconomic assessment of chemical looping reforming of natural gas for hydrogen production and power generation with integrated CO2capture. Int. J. Greenh. Gas Control 78, 7-20. https://doi.org/10.1016/j.ijggc.2018.07.022.

Noorman, S., Annaland, M.V.S., Kuipers, H., 2007. Packed Bed Reactor Technology for Chemical-Looping Combustion. Ind. Eng. Chem. Res. 46, 4212-4220. https://doi. org/10.1021/ie061178i.

Ortiz, M., Abad, A., de Diego, L.F., García-Labiano, F., Gayán, P., Adánez, J., 2011. Optimization of hydrogen production by Chemical-Looping auto-thermal Reforming working with Ni-based oxygen-carriers. Int. J. Hydrogen Energy 36, 9663-9672. https://doi.org/10.1016/j.ijhydene.2011.05.025.

Ortiz, M., de Diego, L.F., Abad, A., García-Labiano, F., Gayán, P., Adánez, J., 2010. Hydrogen production by auto-thermal chemical-looping reforming in a pressurized fluidized bed reactor using Ni-based oxygen carriers. Int. J. Hydrogen Energy 35, 151-160. https://doi.org/10.1016/j.ijhydene.2009.10.068.

Pans, M.A., Abad, A., de Diego, L.F., García-Labiano, F., Gayán, P., Adánez, J., 2013. Optimization of $\mathrm{H} 2$ production with $\mathrm{CO} 2$ capture by steam reforming of methane integrated with a chemical-looping combustion system. Int. J. Hydrogen Energy 38, 11878-11892. https://doi.org/10.1016/j.ijhydene.2013.06.114. 
Riva, L., Martínez, I., Gallucci, F., van Sint Annaland, M., Romano, M.C., 2018. Technoeconomic analysis of the $\mathrm{Ca}-\mathrm{Cu}$ process integrated in hydrogen plants with $\mathrm{CO} 2$ capture. Int. J. Hydrogen Energy 43, 15720-15738. https://doi.org/10.1016/j ijhydene.2018.07.002.

Ryden, M., Lyngfelt, a, 2006. Using steam reforming to produce hydrogen with carbon dioxide capture by chemical-looping combustion. Int. J. Hydrogen Energy 31, 1271-1283. https://doi.org/10.1016/j.ijhydene.2005.12.003.

Sinnott, R.K., Towler, G., 2013. Chemical Engineering Design. Chemical Engineering Design. https://doi.org/10.1016/C2009-0-61216-2.

Smith, A.R., Klosek, J., 2001. A Review of Air Separation Technologies and Their Integration with Energy Conversion Processes. Fuel Process. Technol. 70, 115-134. https://doi.org/10.1016/S0378-3820(01)00131-X.

Smith, R., 1994. Chemical Process Design and Integration. John Wiley \& Sonshttps://doi. org/10.1016/0011-9164(94)85156-5.

Song, T., Shen, L., 2018. Review of reactor for chemical looping combustion of solid fuels. Int. J. Greenh. Gas Control 76, 92-110. https://doi.org/10.1016/j.ijggc. 2018.06.004.

Spallina, V., Chiesa, P., Martelli, E., Gallucci, F., Romano, M.C., Lozza, G., van Sint Annaland, M., 2015a. Reactor design and operation strategies for a large-scale packed-bed CLC power plant with coal syngas. Int. J. Greenh. Gas Control 36, 34-50. https://doi.org/10.1016/j.ijggc.2015.01.025.

Spallina, V., Gallucci, F., Romano, M.C., Chiesa, P., Lozza, G., van Sint Annaland, M., 2013. Investigation of heat management for CLC of syngas in packed bed reactors. Chem. Eng. J. 225, 174-191. https://doi.org/10.1016/j.cej.2013.03.054.

Spallina, V., Gallucci, F., van Sint Annaland, M., 2019. Chapter 3: Chemical Looping Processes Using Packed Bed Reactors. Handbook of Chemical Looping Technology. p 488.

Spallina, V., Hamers, H.P., Gallucci, F., Van Sint Annaland, M., 2015b. Chemical Looping Combustion for Power Production. Process Intensification for Sustainable Energy Conversion. https://doi.org/10.1002/9781118449394.ch5.

Spallina, V., Marinello, B., Gallucci, F., Romano, M.C., Van Sint Annaland, M., 2017a Chemical looping reforming in packed-bed reactors: Modelling, experimental validation and large-scale reactor design. Fuel Process. Technol. 156, 156-170. https:// doi.org/10.1016/j.fuproc.2016.10.014.

Spallina, V., Pandolfo, D., Battistella, A., Romano, M.C., Van Sint Annaland, M., Gallucci, F., 2016. Techno-economic assessment of membrane assisted fluidized bed reactors for pure H2 production with CO2 capture. Energy Convers. Manag. 120, 257-273. https://doi.org/10.1016/j.enconman.2016.04.073.

Spallina, V., Shams, A., Battistella, A., Gallucci, F., van Sint Annaland, M., 2017b. Chemical Looping Technologies For H2 Production With CO2 Capture: Thermodynamic Assessment And Economic Comparison. Energy Procedia 114, 419-428. https://doi.org/10.1016/j.egypro.2017.03.1184.

Stenberg, V., Rydén, M., Mattisson, T., Lyngfelt, A., 2018. Exploring novel hydrogen production processes by integration of steam methane reforming with chemicallooping combustion (CLC-SMR) and oxygen carrier aided combustion (OCAC-SMR). Int. J. Greenh. Gas Control 74, 28-39. https://doi.org/10.1016/j.ijggc.2018.01.008.

Symonds, R.T., Sun, Z., Ashrafi, O., Navarri, P., Lu, D.Y., Hughes, R.W., 2019. Ilmenite ore as an oxygen carrier for pressurized chemical looping reforming: Characterization and process simulation. Int. J. Greenh. Gas Control 81, 240-258. https://doi.org/10. 1016/j.ijggc.2018.12.006.

Tang, M., Xu, L., Fan, M., 2015. Progress in oxygen carrier development of methane-based chemical-looping reforming: A review. Appl. Energy 151, 143-156. https://doi.org/ 10.1016/j.apenergy.2015.04.017.

Tso, W.W., Niziolek, A.M., Onel, O., Demirhan, C.D., Floudas, C.A., Pistikopoulos, E.N., 2018. Enhancing natural gas-to-liquids (GTL) processes through chemical looping for syngas production: Process synthesis and global optimization. Comput. Chem. Eng. 113, 222-239. https://doi.org/10.1016/j.compchemeng.2018.10.017.

Wassie, S.A., Cloete, S., Spallina, V., Gallucci, F., Amini, S., van Sint Annaland, M., 2018a. Techno-economic assessment of membrane-assisted gas switching reforming for pure H2 production with $\mathrm{CO} 2$ capture. Int. J. Greenh. Gas Control 72, 163-174. https:// doi.org/10.1016/j.ijggc.2018.03.021.

Wassie, S.A., Medrano, J.A., Zaabout, A., Cloete, S., Melendez, J., Tanaka, D.A.P., Amini, S., van Sint Annaland, M., Gallucci, F., 2018b. Hydrogen production with integrated $\mathrm{CO} 2$ capture in a membrane assisted gas switching reforming reactor: Proof-ofConcept. Int. J. Hydrogen Energy 43, 6177-6190. https://doi.org/10.1016/j. ijhydene.2018.02.040.

Zaabout, A., Dahl, P.I., Ugwu, A., Tolchard, J.R., Cloete, S., Amini, S., 2019. Gas Switching Reforming (GSR) for syngas production with integrated CO2 capture using iron-based oxygen carriers. Int. J. Greenh. Gas Control 81, 170-180. https://doi.org/ 10.1016/j.ijggc.2018.12.027. 